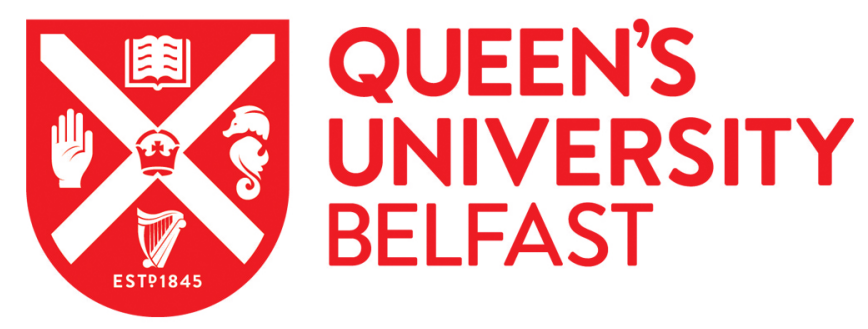

\title{
Plating up appropriate portion sizes for children: a systematic review of parental food and beverage portioning practices
}

Kairey, L., Matvienko-Sikar, K., Kelly, C., McKinley, M. C., O'Connor, E. M., Kearney, P. M., Woodside, J. V., \& Harrington, J. M. (2018). Plating up appropriate portion sizes for children: a systematic review of parental food and beverage portioning practices. Obesity Reviews, 19(12), 1667-1678. https://doi.org/10.1111/obr.12727

Published in:

Obesity Reviews

Document Version:

Peer reviewed version

Queen's University Belfast - Research Portal:

Link to publication record in Queen's University Belfast Research Portal

Publisher rights

(c) 2018 World Obesity Federation.

This work is made available online in accordance with the publisher's policies. Please refer to any applicable terms of use of the publisher.

\section{General rights}

Copyright for the publications made accessible via the Queen's University Belfast Research Portal is retained by the author(s) and / or other copyright owners and it is a condition of accessing these publications that users recognise and abide by the legal requirements associated with these rights.

Take down policy

The Research Portal is Queen's institutional repository that provides access to Queen's research output. Every effort has been made to ensure that content in the Research Portal does not infringe any person's rights, or applicable UK laws. If you discover content in the Research Portal that you believe breaches copyright or violates any law, please contact openaccess@qub.ac.uk. 


\section{Plating up appropriate portion sizes for children: a systematic review of parental food and beverage portioning practices}

\section{Summary}

Consumption of larger portion sizes is associated with higher energy intake and weight status in children. As parents play a pivotal role in child feeding, we synthesized literature on 'parental portioning practices' using a mixed methods systematic design to inform future strategies addressing portion sizes served to children. Electronic databases PubMed, EMBASE, SCOPUS, PsycINFO and CINAHL Plus were searched. Two reviewers independently screened 385 abstracts and assessed 71 full-text articles against eligibility criteria: studies assessing portioning of foods or beverages by parent(s) with $\geq 1$ child aged $2-12$ years. Narrative synthesis of 14 quantitative studies, found portion sizes parents serve vary substantially and are influenced by amounts parents serve themselves, perceived child hunger, and parent and child body size. Thematic synthesis of 14 qualitative studies found parents serve the portion sizes they learn to be appropriate for their child to be fed. Portioning is influenced by parents' desires for a healthy child with a balanced diet. Future guidance on appropriate portion sizes for children would ideally present recommended portion sizes for first serving, incremental with age. Future research is however, needed to assess the adoption and efficacy of providing such guidance to families. 


\section{Introduction}

Childhood overweight and obesity remains a global public health challenge. The sizes in which commercially produced foods and beverages are sold have increased in recent decades (1-3), as have the portion sizes children consume, in particular, energy-dense foods and beverages (e.g. crisps, cakes, biscuits, ice-creams, and sugar-sweetened beverages) $(4,5)$. Of primary concern, is children's consumption of such foods and beverages in larger portion sizes, as this is associated with higher energy intake and body size (6-8).

The mechanism behind these observations has been termed the 'portion size effect', whereby, serving larger portion sizes increases the volume of a food or beverage consumed. In children, doubling the portion size served increases the volume consumed by approximately $20 \%$, although effects vary by child age and weight status $(9,10)$. Effects are also exacerbated by energy density, having an additive effect to portion size (i.e. children consume more when served a larger portion size and more again if the food or beverage is energy-dense) (11). Critically, children may not compensate for the additional energy consumed from larger portion sizes at other meals (12). Thus, moderating portion sizes served to children, particularly portion sizes of energy-dense foods and beverages, is important to preventing excessive energy intake in children.

Portion sizes served to children for meals and snacks are often determined by parents or guardians (13). Children learn what and how much to consume through social modelling of their parents' eating $(14,15)$. Parents also use different feeding practices to develop eating habits they deem appropriate in their children (14). Parents are therefore a primary target for moderating portion sizes served to children and fostering healthy portion size habits in children. How parents portion foods or beverages for their child (i.e. 'parental portioning practices') however, remains an understudied aspect of 
parental feeding (16). Understanding how parents portion food for their children, and factors influencing this, is important to inform the design of future strategies to moderate portion sizes served to children. We therefore aimed to synthesize literature on the portioning practices of parents with children aged 2-12 years, including factors influencing these practices, using a mixed methods systematic design. Our specific research question was 'what practices are used by parents to portion food and beverages for their child and what factors influence these practices?'

\section{Methods}

The protocol for this review is registered in PROSPERO (CRD42017067613). This review is reported in accordance with the 2009 PRISMA Statement.

\section{Search strategy}

Eligibility criteria for the included studies are presented in Box 1 according to the SPIDER framework (17), with further explanation and elaboration. Electronic databases PubMed, EMBASE, SCOPUS, PsycINFO and CINAHL Plus were searched from inception to May 2018. We compiled initial search terms using MeSH and Emtree databases, e.g. 'portion size', 'meal', 'snack', 'beverage', 'parent', 'child', 'knowledge', 'perceptions' and 'practices'. These terms were then compared to keywords of relevant articles identified from preliminary Internet and Google Scholar scoping searches to create a comprehensive list of MeSH and Emtree terms and additional keywords to capture articles not yet indexed. Table S1 illustrates the final search strategies used. Electronic database searches were supplemented by the OpenGrey database (http://www.opengrey.eu/) and hand searching citations from existing reviews in this field that were identified from electronic database searches or review registries (PROSPERO and Cochrane). Articles retrieved from all sources were exported into Endnote X8 (Thomson Reuters, Philadelphia, United States (US)) where duplicates were removed. Remaining 
articles were exported into Covidence (Veritas Health Innovation Ltd, Victoria, Australia) for systematic screening of titles and/or abstracts and full-text eligibility assessment.

\section{[Insert Box 1 here]}

\section{Study selection}

Author (LK) and research intern (AHB) independently screened all abstracts against eligibility criteria and proceeded to assess the full-text of eligible abstracts or abstracts providing insufficient information for a decision on eligibility. Disagreements were discussed and co-authors KMS and JH consulted where consensus was not achieved.

\section{[Insert Figure 1 here]}

\section{Data extraction}

One reviewer (LK) extracted data from quantitative and qualitative studies separately using a standardized data extraction form (Table S2). The results sections of qualitative articles were imported into NVivo 11 qualitative data management software (QSR International Pty Ltd., Victoria, Australia) for thematic synthesis. These data included both participant quotations and authors' interpretations. We omitted text irrelevant to parental portioning practices e.g. parents' views on their child's physical activity, screen time, active play, or tooth decay prevention from three studies with research aims beyond child feeding (18-20), to ensure our qualitative data remained relevant to the research question.

\section{Quality appraisal}


Quality of included studies was assessed using the Mixed Methods Appraisal Tool (MMAT), given the applicability of assessment items to the study designs included in this review (21). Quality assessments were conducted independently by two co-authors for quantitative ( $\mathrm{LK}$ and $\mathrm{JH}$ ) and qualitative studies (LK and KMS), with disagreements resolved by consensus. Quality assessment criteria and overall scores were tabulated and presented graphically (Figures 2 and 3).

\section{Synthesis of results}

Findings from quantitative studies were summarized narratively guided by methods described by Popay et al. (22). Quantitative results on the review outcome were extracted and summarized according to explanatory measures (i.e. factors influencing parental portioning practices). Results for similar explanatory measures were compared and reported by selected sample characteristics and setting to inform generalizability. Qualitative data were synthesized thematically guided by methods described by Thomas and Harden (23). One reviewer (LK) initially coded all qualitative data line-byline into 'free' codes. As each new study was coded, new free codes were developed and existing codes revised. At this stage, free codes remained close to the data. Free codes were then compared and contrasted by LK to refine, create new, and/or remove codes and structure codes into logical thematic hierarchies. Third-order author interpretations 'themes' were then constructed by relating thematic hierarchies back to our initial research question. We retained only those themes representing data from more than one subject. Each stage of the thematic synthesis was independently assessed by co-author KMS.

\section{Results}

\section{Study characteristics}


Of 385 unique records screened, 71 full-text articles were assessed against eligibility criteria and 28 included (14 quantitative, 14 qualitative; Figure 1). Tables 1A and 1B summarize the included quantitative and qualitative studies, respectively. Participating parents resided mostly in the US (quantitative 11/14; qualitative 10/14) and were predominantly female (quantitative: $100 \%$ in $3 / 14$, $79 \%-95 \%$ in $7 / 14$, gender not reported $4 / 14$; qualitative: $100 \%$ in $6 / 14,79 \%-94 \%$ in $6 / 14$, gender not reported 2/14). Almost half were conducted with specific ethnic groups and/or groups of lower income and/or education status (quantitative 5/14; qualitative 7/14). Ages of parents' children were younger in qualitative studies ( $1-5$ years in $9 / 14,5-13$ in 3/14, and 2-12 in 1/14), compared with quantitative studies (2-6 years in 5/14 studies, $5-12$ in $6 / 14$, and 3-13 in 3/14). Most quantitative studies were observational (12/14) and used questionnaires (24-29), portion size estimation or portioning tasks (30-33), a home meal portioning observation (34), or a computer-assisted interview (35). Remaining quantitative studies (2/14) were experimental in design but reported data from baseline questionnaires $(36,37)$. Qualitative studies used either focus groups (18-20, 38-43) or interviews (44-48), and analyzed data using content analysis methods (12/14), or grounded theory (41, 46). One study coded text for 'portion size' as a pre-defined theme (45). Two mapped resulting themes into domains of healthy eating, physical activity, and weight-management (41), or against two theoretical behavior change models (39).

\section{Quality appraisal}

Figures 2 and 3 illustrate the quality of quantitative and qualitative studies, respectively, according to MMAT criteria. Quantitative studies scored highly on recruiting relevant samples for their stated research question(s) and reporting sources of, and/or validity or reliability for, measurement tools used. Quality scores were however, reduced by poor reporting of response rates and/or representativeness of samples recruited.

\section{[Insert Figure 2 here]}


Qualitative studies scored highly on the relevance of samples recruited and data analysis methods for answering the research question(s). Quality scores were reduced where the influence of either the researcher(s) and/or study context on findings was not reported, or potential selection bias from recruitment sources $(38,44)$.

\section{[Insert Figure 3 here]}

\section{Narrative summary of quantitative studies}

\section{Parental concern about child portion sizes}

Edwards et al. surveyed parents ( $79 \%$ female) of low to middle socioeconomic status during a routine child health assessment (36). Seventy-five percent reported the portion sizes eaten by their child (aged 9-12 years) as 'about right', compared with $23 \%$ as 'too much' (36). Most (53\%) of children were overweight or obese (36). Asante et al. surveyed parents during a routine health assessment for their child (age in years: $\mathrm{M}=8.5, \mathrm{SD}=3.1$ ) (24). Fifty-eight percent were willing to decrease family meal portion sizes, compared with eating more fruit or vegetables ( $87 \%$ and $85 \%$, respectively), drinking less sugar-sweetened beverages (85\%), or eating less fast food (83\%) (24). More parents of children with overweight or obesity were willing to decrease family meal portion sizes than parents of children with a healthy weight ( $68 \%$ versus $49 \%, P=0.001)(24)$. Similarly, Campbell et al. surveyed parents of children (age in years: $\mathrm{M}=11.3, \mathrm{SD}=3.1$ ) with obesity during a weight control clinic visit (25). Thirteen percent reported controlling portion sizes as important to family weight management, compared with physical activity (63\%), eating fruit and vegetables $(17 \%)$, or reducing sugarsweetened beverages (4\%) (25). Ohly et al. surveyed parents (94\% female) of children aged 2-5 years, whom half agreed that learning about appropriate child portion sizes would be 'very useful' (27). More parents of low educational attainment agreed with this, compared with medium or high (59.2\% versus $55.0 \%$ or $36.4 \%, P<0.01)(27)$. 


\section{Parental estimation of appropriate portion sizes}

Fulkerson et al. measured parents' self-efficacy in identifying appropriate portion sizes (for their child and others). Prior to intervention, parents reported a mean (SE) self-efficacy score of $10.8(0.26)$, from a possible score range of $4-16$ (37). Robson et al. quantified parents' estimates of appropriate portion sizes for their child (aged 3-10 years) using a visual portion size estimation task (31). Parents over-estimated a 'conventional' child portion size of baked chicken ( 85 grams) by a mean 42.52 (SD $=51.03)$ grams, while a child portion size of kernel corn ( 0.12 liters $)$ was more accurate $(\mathrm{M}=-0.05$, $\mathrm{SD}=0.02)(31)$. Parents were mostly female $(85 \%)$, with overweight or obesity $(82 \%)$, and held a college degree or higher (85\%) (31). Croker et al. quantified typical portion sizes mothers served their child (aged 8-11 years) using a practical weighing task (38). Mothers served smaller portion sizes of breakfast cereals and grated cheese, compared with chicken, pasta and peas, with substantial variation between mothers' portion sizes, particularly for main meal items (chicken, pasta and peas) (38). Vittrup et al. surveyed parents of younger children $(\mathrm{M}=4.4, \mathrm{SD}=1.7)$, of whom $34 \%$ reported not knowing how they determine portion sizes for their child (29). Other parents gauged portion sizes by how much they thought their child would eat (19\%) or used specific resources to determine portion sizes including spoons or measuring cups (14\%), size of the child's fist/palm (12\%) and serving size information on food labels or existing portion size charts (10\%) (29). Using a visual portion size estimation task, Potter et al. showed a positive correlation between the portion size a parent thought perfect for their child (aged 5-11 years) to eat for dinner and the portion size their child thought perfect for themselves $(r=0.15, P<0.05)$ (30). Equally, the maximum portion size a parent thought their child would eat for dinner correlated positively with the maximum portion size their child thought they would eat for dinner $(r=0.22, P<0.001)(30)$. Marx et al. surveyed parents $(85 \%$ female) of 4-6 year old children, finding parents more frequently classified a 'large portion' as a meal and a 'small portion' as a snack (26). Dallacker et al. showed an association between lower numeracy scores and less accurate portion size estimation $(r=-0.08, P=0.023)$ among parents $(86 \%$ female) 


\section{Child self-serving versus parents serving}

Hoffmann et al. surveyed mothers of children aged $7-11$ years, who reported a slightly higher proportion of their children 'often' or 'always' self-serve their breakfast, lunch, dinner, and dessert on weekend days $(37 \%, 26 \%, 12 \%$, and $23 \%$, respectively), compared with weekdays (32\%, $19 \%, 9 \%$, and 19\%, respectively) (28). Snacks however, were reported to be self-served by children 'often' or 'always' at a similar frequency on weekend days (61\%) and weekdays (62\%) (28).

\section{Relativity to parent's portion size}

Johnson et al. showed a positive association between the total energy parents served their child (aged $\sim 4.5$ years) and themselves ( $r=0.51, P<0.0001)$, at the evening meal (34). At evening meals where parents served themselves more than they typically would, they also served more to their child $(P<$ $0.0001)(34)$.

\section{Parental and child hunger}

Stromberg et al. showed mothers served more energy to their child at a buffet meal when they perceived their child hungrier $(\beta=77.95, P=0.032)$ (33). Hungrier mothers perceived their children as hungrier ( $\beta=0.339, P=0.02$ ), and among mothers with obesity, mothers' perception of their child's hunger mediated the relationship between a mother's hunger and energy served to their child (33).

\section{Anthropometric characteristics}

Stromberg et al. further found that mothers served more energy to their child if the child was classified as overweight or obese, compared with a healthy weight (calories: $\mathrm{M}=751.19, \mathrm{SD}=331.2$; versus $\mathrm{M}=526.7, \mathrm{SD}=157.0$ ) (33). Similarly, Potter et al. showed a parents' ideal portion size for their child correlated positively with parent BMI $(r=0.22, P<0.001)$ and child BMI percentile $(r=$ $0.39, P<0.001)(30)$. In a buffet style meal serving task where mothers served themselves and their 
child a plate of food from the foods provided (e.g. pasta, meat sauce, salad), Silvia-Garcia et al. demonstrated a positive correlation between child BMI z-score and less food restriction by mothers, i.e. mothers of heavier children more often allowed their child to have foods they desired $(r=0.14, P$ $=0.05)(32)$. Asante et al., found equal proportions of parents of children with overweight or obesity (16\%), or a healthy weight (16\%), reported their child asks for second helpings at dinner (24).

\section{Demographic characteristics}

Silvia-Garcia et al. also found a positive association between child age in months and mothers' allowing children to serve themselves and/or determine how much food they are served $(r=0.15, P=$ 0.05 , children aged 4-5 years) (32). Mothers also restricted foods from boys more often than girls $(r=$ $0.16, P=0.05)(32)$. Johnson et al. showed parent of Hispanic/Latino ethnicity served less total energy to their child compared with parents of African American ethnicity $(P=0.004)(34)$. Compared with unemployed parents, employed parents served more energy to their children $(P=$ 0.025), adjusting for parent ethnicity (34). Further, Johnson et al. found no differences in amounts parents served by child gender (34).

\section{Thematic synthesis of qualitative studies}

'Parental portioning practices' was framed in qualitative literature as the decision parents make on the amount (portion size) of a food or beverage to serve their child. Three themes emerged: 1) parentrelated factors, 2) child-related factors, and 3) external factors, comprising multiple, inter-connected sub-themes.

\section{Theme 1. Parent-related factors}

\section{Sub-theme 1.1. Balance precedes portion size}

Parents in six studies $(19,20,38,44,46,48)$ identified a balanced intake of food groups as a primary 
child feeding goal (" "The meal must have proteins, chicken or fish ... or from time to time meat. Yes, that's important for me, to have proteins, so the meal is balanced, as balanced as possible."'(48)). In two studies $(19,38)$, portion size was of lesser concern to parents than this balance at meals ('Mothers were almost universally unconcerned about the issue of portion sizes, "It is about combinations for me, so portion size is not that much of an issue."' (38)). Parents' unconcern about portion sizes was further expressed in four studies $(19,38,39,45)$, as 'routine' or 'guessed' portion sizes served to children (““Most parents just guess on portions”.' (19); ““I don’t know. It’s just routine...”.' (45)).

\section{Sub-theme 1.2. Desire for a healthy child (of a healthy weight)}

Parents in four studies $(39,40,44,46)$ wanted their child to be a healthy or 'normal' weight, as this indicated their child was healthy ('Mothers were focused on what they perceived as healthy growth for their child. "It's really important [to gain the right amount of weight] because that way I know whether she is healthy or not".' (46)). Parents of young children (aged 2-5 years) in two studies (19, 40) expressed desire for their child to be slightly overweight to prevent ill-health ('...having a 'chubby' child was viewed as a positive thing by many; needing 'a little bit of extra padding' to cope with active play, illness and 'growth spurts'.' (40)). However, parents also expressed desire to prevent too much weight gain and would restrict portion sizes if believed in the child's best interest (" I I just don't want them to eat too much or gain weight then there will be a health problem to deal with".' (44)).

\section{Sub-theme 1.3. Need to ensure their child is fed}

Parents in five studies $(19,20,44,46,48)$ expressed a need to ensure their child was fed as they perceived this to be their role as a parent (" My role...is to try and make sure that they have a wellbalanced meal...as long as there's like a vegetable, some bread, definitely milk and meat...that's like the most important thing to have as many food groups as possible. And then to try and make sure that they eat at least enough where I feel that they're fed. Like I'll say, 'Are you full now?' And I want to make sure because that's just my job".' (44)). Parents in three studies $(40,44,46)$ reported feeling happy to 
see their child eating 'enough', particularly of the types of foods they wanted them eating (" II would feel really happy if he ate this because I would see him as eating good...Enough [of the] portions that I would want him to eat".' (46)). Parents in four studies $(19,20,44,46)$ served their children the types and amounts of foods they liked to ensure they ate. The notion of restricting food from a hungry child to prevent weight gain created anxiety among parents $(40,44)$, ('The dilemma mothers seemed to face was their concern not to 'give in' [to food demanded outside mealtimes], causing their child to put on too much weight, yet...fearing that their child might genuinely need the extra nourishment...' (40)). Parents in one study however, described limiting food outside of meal times to avoid children developing a habit of snacking (48).

\section{Sub-theme 1.4. Have learned the portion sizes their child will eat}

Parents in four studies $(18,20,38,46)$ stated they simply knew the portion sizes their child would eat. This understanding of their child's ideal portion sizes developed over time with experience of their child's eating patterns ('Many mothers asserted that the amounts they served were based on knowing their child and knowing what the "right amount" for their child was because of their long-time experience with feeding their child.' (46)). In deciding portion sizes to serve, this understanding was contextualized with in-the-moment factors such as time since the child last ate, prior intake that day, usual eating routine, expressions of hunger, and physical state (i.e. parents knew a tired or unwell child would eat less $)(18,20,38,45,46)$. Parents in two studies $(38,40)$ interpreted their child's ideal portion sizes as highly individual from comparison to other children or siblings' consumed portion sizes ('There was a widespread belief that all children are different and that the right amount for one particular child would be too much or too little for another.' (38)).

\section{Sub-theme 1.5. Onus of control over portion size}

Parents in five studies $(18,19,38,44-46)$ allowed their child to self-regulate their intake at meals. In these studies, the child was also permitted autonomy to decide their own portion size (" "I don't decide the amount until she tells me, 'Okay', she doesn't want any more”.' (45)). Other parents interpreted their 
child's expression of satiety to mean something else (e.g. 'wanting to do something else') and encouraged their child to continue eating $(20,46)$. Alternatively, parents negotiated portion sizes with their child $(18,38,45,47,48)$ ('“'Last night when I put their food on their plates she said: oh, you haven't given me enough. I said you can have one more piece of chicken but you're not having anything else".' (38)).

\section{Sub-theme 1.6. Desire to avoid waste of time and food (money)}

Parents in three studies $(19,44,46)$ wanted their child to eat what they viewed a reasonable amount of their evening meal to avoid wasting food (and therefore money), as well as their time preparing uneaten food. Further, there was evidence from one study that parents believed they would overfeed (or over-portion) a child to avoid wasting food prepared in surplus (" "So if you've over cooked, you will overfeed...I don't like to throw it in the bin so it goes on the plate”.' (39)).

\section{Sub-theme 1.7. Knowledge of portion sizes}

Parents in four studies $(19,38-40)$ expressed limited knowledge of appropriate portion sizes for children and themselves ( ““...I find it particularly difficult dishing out the correct portion size for children and for adults, I suppose. I just tend to give everybody the same amount”.' (39)). Parents in three studies $(19,39,44)$ referred to a child portion as smaller than an adult portion, with one specific portioning strategy being 'cutting adult portions in half' (19). Parents in three studies $(45,47,48)$ defined a snack as 'something small' or a 'small portion of food'.

\section{Theme 2. Child-related factors}

\section{Sub-theme 2.1. Age and developmental stage}

Parents in four studies $(19,38,40,44)$ described portion sizes as needing to increase as a child grows older and for developmental 'growth spurts' (““...she eats way smaller than the older two because she is younger. I feed her smaller amounts too because she is younger and doesn't need as much [as] them 
[older siblings]".' (44)). Other parents $(39,40)$ however, served their children the same portion sizes regardless of age ('P11: “My two get the same size and that's them three and six, you know...” P08:

"So do mine".' (40)).

\section{Sub-theme 2.2. Body size and weight status}

Parents in two studies $(41,44)$ who perceived their child as carrying too much weight, restricted their child's portion sizes and/or third helpings (" WWe do try to portion foods for Jerome because he's a little on the heavier side".'; “'I'll say to the bigger child, 'That's enough. You already have 2 plates...”.'

(44). While other parents $(40,44)$ would not feed their child differently due to their weight to avoid discrimination (' "I wouldn't change how I feed her because she's overweight. I don't want her to think that there's anything wrong with how she is".' (44)). Conversely, in three studies $(40,44,45)$, when parents or others such as family perceived the child as too thin they did not restrict the child's portion sizes, allowed third helpings if desired, and encouraged continued eating even in the absence of hunger (“'If Joe would have wanted thirds, we would have let him, because he's always really thin”.'; “"She’s tiny...Even if she says she’s not hungry, I'll just be like 'Well, just eat a little bit'”.' (44)).

\section{Theme 3. External factors}

\section{Sub-theme 3.1. Perceived healthfulness of a food or beverage}

Parents in eight studies $(18-20,38,40,44-46)$ tried to balance their child's intake of perceived less healthy and healthier foods and beverages ('“I feel like she didn't eat that fruit... it's like a trade-off. You don't get the cookie”.' (18)). Parents in six studies $(18-20,38,45,48)$ restricted portion sizes of perceived less healthy foods or beverages ( ““...when it comes to things that are not so healthy I just tell him, you know. One ice cream sandwich is enough".' (45)). Parents reported different practices for this, including hiding foods or beverages, controlling portions ( "I don't give them two pop tarts. I give them one per child. They don't get a whole pop tart pack".' (45)), using smaller serving ware ( '...to control portion sizes of sugar-sweetened beverages ("only give them a small cup”).' (19)), or not 
buying them in the first instance. Parents in two studies also used less healthy foods as a contingency to encourage consumption of healthier foods (" "So, if you want some cake, you are going to eat this!".' $(18,46))$. Indulgent feeding practices of male partners or spouses frustrated female parents in four studies $(18,39,40,42)$ who reported them to serve larger portions than they would, particularly of less healthy foods. Perceived healthier foods or beverages were offered to hungry children thought to have already eaten enough (" "You're not getting thirds...Dinner is done. You can drink some water, eat a piece of fruit, that's it”.' (44)), were permitted to be consumed by children ad libitum ( “If it's healthy I'll tend to give her more of the item, whatever it is".' (45)), and were used to balance-out less healthy food or drink intake (" "So I'll give her that [peanut butter and jelly...], but she has to eat a vegetable”.' (18)).

\section{Sub-theme 3.2. Portioning resources}

In two studies $(19,45)$, parents with younger children (aged 2-5 years) described using resources such as pre-portioned child snacks or child serving ware (e.g. 'child-sized' plates, bowls, and cups) to simplify, or replace entirely, their decision on the portion size to serve. Pre-packaged single portion snacks were purchased for their convenience and to restrict portion sizes of perceived less healthy foods (“"Um, the potato chips, I buy the small bag. So when it’s finished, that's it”.' (45); “"While on the road... a juice box is easier". ' (19)). Hand or finger sizes were viewed as convenient for deciding portion sizes without needing utensils or containers (45). Few reported using measuring cups or weighing foods to determine portion sizes $(19,45)$. Parents in two studies $(38,39)$ were unfamiliar with weighed portions and expressed unwillingness to weigh foods for their child ("“I hadn't really got a clue about how much makes $30 \mathrm{~g}$, or $60 \mathrm{~g}$ ”. ' (38); “ “I still don't have time to figure out...I just don't want to”.' (39)).

\section{Sub-theme 3.3. Authoritative guidance}

Parents in two studies $(19,20)$ expressed a desire for information on appropriate portion sizes for their preschool aged child and on who should decide portion sizes. Other parents (19) however, agreed 
more guidance would not be welcomed due to existing 'information overload' (38). Yet, parents in three studies $(19,39,40)$ were unaware of existing guidance on child portion sizes ('“I don't think there is any guidance for portion sizes, I mean until you mentioned it and I felt oh actually yeah I think that's an issue with our house". '(39)). 


\section{Discussion}

Our aim was to synthesize literature on 'parental portioning practices' and factors influencing these practices. 'Parental portioning practices' were framed in the literature as the portion size (or amount) of a food or beverage a parent serves their child and how parents' decide these amounts. Ultimately, parents serve the portion sizes they have learned to be appropriate (or 'enough') for their child to be fed. These learned portion sizes differ from child-to-child, as parents view children as highly individual in the amounts of food they need. Parents aim to ensure their child eats a 'balanced' intake of less healthy and healthier foods and beverages. Achieving this is of greater concern to parents than portion sizes they consume. Parents are also generally content with and confident in the appropriateness of the portion sizes they serve. However, parents also need to feel their child is fed, viewing this as their role as a parent, and will serve their child the types of foods in the amounts preferred to ensure intake. Other factors influencing parental portioning include the amounts parents serve themselves, perceived child hunger, parent and child body size, and parental employment status. In reality, our findings represent 'maternal', rather than 'parental', portioning practices, due to the dominance of female subjects studied. This also signifies however, that females continue to dominate in child feeding roles.

We found that the portion sizes parents serve are those learned to be 'enough' for their child to be fed. This practice is consistent with how adults serve themselves at meals, with portion sizes determined by the amounts they plan to consume (49). Deciding portion sizes for a child to consume however, may be counter-intuitive to developing a child's ability to self-regulate intake based on hunger and fullness $(15,50)$. We found that some parents permit children to decide their own portion sizes and others have shown that when children are permitted to do so they consume less food than if served a large portion (48). 
Given parents' limited knowledge of appropriate portion sizes for children and themselves reported in this review, education as an obesity prevention strategy may moderate portion sizes served to children. Parents' self-efficacy in serving appropriate portion sizes can be increased by engaging parents in practical food preparation tasks that generate discussion and sharing of experiences among parents regarding portioning for their children and others $(37,51)$. Parents can also learn to estimate portion sizes more accurately through interactive group sessions using physical food models (52). Further, children can be trained to estimate portion sizes more accurately by making sequential comparisons between foods, measuring cups, and other portion size aids (e.g. golf ball, baseball) (53). Another strategy is to reduce children's energy intake from a larger portion size by serving a low energy density entrée (i.e. vegetables or salad) before the main meal or reducing the energy density of a meal by incorporating more vegetables or fruit into the meal (54-58). Such strategies also increase children's fruit and vegetable intake and may be of greatest relevance to children with obesity, who have been reported to require approximately $20 \%$ more food to feel satiated (59).

Asante et al. (24), reported that parents of children with overweight or obesity are more willing to reduce family portion sizes, compared with parents of children with a healthy weight. Why parents were more willing is unclear, although when parents perceive their child as overweight, readiness to change their child's diet is increased. This is supported by our finding that parents adopt different portioning practices based on their perception of their child's body size. However, as only half of parents of children with overweight or obesity consider their child overweight $(60,61)$, altering parental perception of what constitutes a healthy weight will be important to changing practices. For children with overweight or obesity, reducing portion sizes consumed is effective for sustained two-year weight loss when delivered as part of mutli-disciplinary program comprising portion size education to children and their parents (62). 
As parents also described using pre-packaged snacks targeted at children (e.g. children's yogurts), effective front-of-package labelling on children's products to enable parents to choose healthier pre-packaged options for their children is also warranted (63). Providing portion size guidance on such products may also support family education on healthy portion sizes for children.

We found parents to be generally unaware of existing authoritative guidance on portion sizes; an unsurprising finding given not all countries incorporate serving size guidance into food based dietary guidelines (64). Providing such guidance however, may be challenged by views parents expressed in this review regarding children being highly individual in the amounts of food they need. Thus, future guidance material for families would ideally be presented as recommended portion sizes for first serving to moderate portion size effects, while communicating the importance of allowing children to self-regulate amounts consumed. As parents view children as needing more food as they grow older, providing guidance according to child age is befitting and consistent with existing food based dietary guidelines (65-67). Guidance could also present recommended portion sizes using resources that we found some parents report using (e.g. hand or finger sizes, child-sizes plates and bowls), given their reported convenience and efficiency for deciding portion sizes.

\section{Future research}

For the purposes of future research, we offer a definition of 'parental portioning practices', based on existing literature, as the practices by which parents or guardians select the portion size (or amount) of a food or beverage to serve their child. Definitions of portion size must also be consistent. 'Portion size' is defined as 'the amount of a food served or consumed in one eating occasion' (68). For research purposes however, portion size consumed is a different outcome to portion size served. In terms of areas where future research is needed, only two studies reported actual quantities 
parents serve to children $(34,38)$. Without such data, it is not possible to monitor changes in parental portioning or establish whether intervention is necessary to reduce portion sizes served. Other areas include 1) the extent to which children are permitted to self-serve and at what age this is initiated, 2) characteristics of families serving 'larger-than-average' portion sizes, and 3) whether children who are served larger portion sizes adapt to consuming larger portion sizes over time, i.e. requiring more food to reach satiety. In regards to the latter, these families would a priority group for intervention, as we found the amount of food parents serve children are intended to ensure their children are satiated (fed). Differences in parental portioning for children with a healthy weight, overweight or obesity also warrants further investigation as few studies have examined this.

\section{Strengths and limitations}

We included a limited scope of grey literature, although preliminary scoping searches indicated relevant literature were confined to the electronic databases we searched. We also found no evidence of studies published in languages other than English. As included studies did not report child health status, parents of children with acute or chronic illness may have been included. Our review is however, is the first to synthesize literature on parental portioning practices for children and involved comprehensive electronic search strategies across six large online databases, including grey literature sources.

\section{Conclusions}

In this review, we synthesized literature on 'parental portioning practices' and factors influencing these practices. We found parents serve the portion sizes they learn to be appropriate for their child to be fed. This differs from child-to-child, as parents view children as highly individual in the amounts of food they need. Portioning practices are primarily influenced by parents' desire for a healthy child and balancing a child's intake of less healthy and healthier foods and beverages. Achieving this is of greater concern to parents than portion sizes consumed. Parents are also generally content with and confident in the appropriateness of the portion sizes they serve. Other factors influencing parental 
portioning include portion sizes parents serve themselves, perceived child hunger, parent and child body size, and parental employment status. Future guidance for parents on appropriate portion sizes for children should ideally be incremental with age, present recommended portion sizes for first serving to moderate portion size effects and emphasize dietary quality and allowing children to self-regulate amounts consumed. Future research is needed however, to assess the adoption and efficacy of providing such guidance to families. 


\section{References}

1. Young LR, Nestle M. Reducing Portion Sizes to Prevent Obesity: A Call to Action. American Journal of Preventive Medicine. 2012;43(5):565-8.

2. Steenhuis IH, Leeuwis FH, Vermeer WM. Small, medium, large or supersize: trends in food portion sizes in The Netherlands. Public Health Nutr. 2010;13(6):852-7.

3. Wrieden W, Gregor A, Barton K. Have food portion sizes increased in the UK over the last 20 years? . The Proceedings of the Nutrition Society. 2008;67((OCE):E211).

4. Kerr MA, Rennie KL, McCaffrey TA, Wallace JM, Hannon-Fletcher MP, Livingstone MB. Snacking patterns among adolescents: a comparison of type, frequency and portion size between Britain in 1997 and Northern Ireland in 2005. Br J Nutr. 2009;101(1):122-31.

5. van der Bend D, Bucher T, Schumacher LT, Collins K, De Vlieger N, Rollo M, et al. Trends in Food and Beverage Portion Sizes in Australian Children; a Time-Series Analysis Comparing 2007 and 2011-2012 National Data. Children. 2017;4(8).

6. Piernas C, Popkin BM. Increased portion sizes from energy-dense foods affect total energy intake at eating occasions in US children and adolescents: patterns and trends by age group and sociodemographic characteristics, 1977-2006. Am J Clin Nutr. 2011;94(5):1324-32.

7. Lioret S, Volatier JL, Lafay L, Touvier M, Maire B. Is food portion size a risk factor of childhood overweight? European journal of clinical nutrition. 2009;63(3):382-91.

8. Huang TT, Howarth NC, Lin BH, Roberts SB, McCrory MA. Energy intake and meal portions: associations with BMI percentile in U.S. children. Obesity research. 2004;12(11):1875-85.

9. Zlatevska N, Dubelaar C, Holden SS. Sizing Up the Effect of Portion Size on Consumption: A Meta-Analytic Review. Journal of Marketing. 2014;78(3):140-54.

10. Kral TVE, Hetherington MM. Variability in children's eating response to portion size. A biobehavioral perspective. Appetite. 2015;88:5-10.

11. Kling SMR, Roe LS, Keller KL, Rolls BJ. Double trouble: Portion size and energy density combine to increase preschool children's lunch intake. Physiology \& Behavior. 2016;162:18-26. 
12. Fisher JO, Arreola A, Birch LL, Rolls BJ. Portion size effects on daily energy intake in lowincome Hispanic and African American children and their mothers. The American Journal of Clinical Nutrition. 2007;86(6):1709-16.

13. McCrickerd K, Forde CG. Parents, portions and potential distortions: Unpicking children's meal size. Nutrition Bulletin. 2016;41(1):67-71.

14. Birch L, Savage JS, Ventura A. Influences on the Development of Children's Eating Behaviours: From Infancy to Adolescence. Canadian journal of dietetic practice and research : a publication of Dietitians of Canada $=$ Revue canadienne de la pratique et de la recherche en dietetique : une publication des Dietetistes du Canada. 2007;68(1):s1-s56.

15. Savage JS, Fisher JO, Birch LL. Parental Influence on Eating Behavior: Conception to Adolescence. The Journal of law, medicine \& ethics : a journal of the American Society of Law, Medicine \& Ethics. 2007;35(1):22-34.

16. Faith MS, Van Horn L, Appel LJ, Burke LE, Carson JAS, Franch HA, et al. Evaluating Parents and Adult Caregivers as "Agents of Change" for Treating Obese Children: Evidence for Parent Behavior Change Strategies and Research Gaps. Circulation. 2012;125(9):1186.

17. Alison C, Debbie S, Andrew B. Beyond PICO: The SPIDER Tool for Qualitative Evidence Synthesis. Qualitative Health Research. 2012;22(10):1435-43.

18. Herman AN, Malhotra K, Wright G, Fisher JO, Whitaker RC. A qualitative study of the aspirations and challenges of low-income mothers in feeding their preschool-aged children. International Journal of Behavioral Nutrition and Physical Activity. 2012;9(1):132.

19. Martin-Biggers J, Spaccarotella K, Hongu N, Alleman G, Worobey J, Byrd-Bredbenner C. Translating it into real life: a qualitative study of the cognitions, barriers and supports for key obesogenic behaviors of parents of preschoolers. BMC Public Health. 2015;15:189.

20. Sherry B, McDivitt J, Birch LL, Cook FH, Sanders S, Prish JL, et al. Attitudes, practices, and concerns about child feeding and child weight status among socioeconomically diverse white, Hispanic, and African-American mothers. Journal of the American Dietetic Association. 2004;104(2):215-21. 
21. Pluye, P., Robert, E., Cargo, M., Bartlett, G., O’Cathain, A., Griffiths, F., Boardman, F., Gagnon, M.P., \& Rousseau, M.C. (2011). Proposal: A mixed methods appraisal tool for systematic mixed studies reviews. Retrieved on 01 August, 2017 from

http://mixedmethodsappraisaltoolpublic.pbworks.com. Archived by WebCite ${ }^{\circledR}$ at http://www.webcitation.org/5tTRTc9yJ.

22. Popay J, Roberts H, Sowden A, Petticrew M, Arai L, Rodgers M, et al. Guidance on the Conduct of Narrative Synthesis in Systematic Reviews: A Product from the ESRC Methods Programme. 2006.

23. Thomas J, Harden A. Methods for the thematic synthesis of qualitative research in systematic reviews. BMC Medical Research Methodology. 2008;8(1):45.

24. Asante PA, Cox J, Sonneville K, Samuels RC, Taveras EM. Overweight prevention in pediatric primary care: a needs assessment of an urban racial/ethnic minority population. Clinical pediatrics. 2009;48(8):837-43.

25. Campbell M, Benton JM, Werk LN. 5-2-1-almost none: parents' perceptions of changing health-related behaviors in their obese child. The Permanente journal. 2009;13(3):4-8.

26. Marx JM, Hoffmann DA, Musher-Eizenman DR. Meals and snacks: Children's characterizations of food and eating cues. Appetite. 2016;97:1-7.

27. Ohly HR, Hayter A, Pettinger C, Pikhart H, Watt RG, Rees GA. Developing a nutrition intervention in children's centres: exploring views of parents in rural/urban settings in the UK. Public Health Nutr. 2013;16(8):1516-21.

28. Hoffmann DA, Marx JM, Burmeister JM, Musher-Eizenman DR. Friday night is pizza night: A comparison of children's dietary intake and maternal perceptions and feeding goals on weekdays and weekends. International Journal of Environmental Research and Public Health. 2018;15(4).

29. Vittrup B, McClure D. Barriers to Childhood Obesity Prevention: Parental Knowledge and Attitudes. Pediatric Nursing. 2018;44(2):81-94.

30. Potter C, Ferriday D, Griggs RL, Hamilton-Shield JP, Rogers PJ, Brunstrom JM. Parental beliefs about portion size, not children's own beliefs, predict child BMI. Pediatr Obes. 2017. 
31. Robson SM, Crosby LE, Stark LJ. Eating dinner away from home: Perspectives of middle-to high-income parents. Appetite. 2016;96:147-53.

32. Silva Garcia K, Power TG, Fisher JO, O'Connor TM, Hughes SO. Latina mothers' influences on child appetite regulation. Appetite. 2016;103:200-7.

33. Stromberg SE, Janicke DM. The relationship between mother to child calories served and maternal perception of hunger. Journal of Human Nutrition and Dietetics. 2016;29(3):290-7.

34. Johnson SL, Hughes SO, Cui X, Li X, Allison DB, Liu Y, et al. Portion sizes for children are predicted by parental characteristics and the amounts parents serve themselves. Am J Clin Nutr. 2014;99(4):763-70.

35. Dallacker M, Hertwig R, Peters E, Mata J. Lower parental numeracy is associated with children being under- and overweight. Social Science \& Medicine. 2016;161:126-33.

36. Edwards BA, Powell JR, McGaffey A, Wislo VMP, Boron E, D'Amico FJ, et al. FitwitsTM Leads to Improved Parental Recognition of Childhood Obesity and Plans to Encourage Change. The Journal of the American Board of Family Medicine. 2017;30(2):178-88.

37. Fulkerson JA, Friend S, Horning M, Flattum C, Draxten M, Neumark-Sztainer D, et al. Family Home Food Environment and Nutrition-Related Parent and Child Personal and Behavioral Outcomes of the Healthy Home Offerings via the Mealtime Environment (HOME) Plus Program: A Randomized Controlled Trial. Journal of the Academy of Nutrition and Dietetics. 2018;118(2):24051.

38. Croker H, Sweetman C, Cooke L. Mothers' views on portion sizes for children. Journal of human nutrition and dietetics : the official journal of the British Dietetic Association. 2009;22(5):43743.

39. Curtis K, Atkins L, Brown K. Big hearts, small hands: a focus group study exploring parental food portion behaviours. BMC Public Health. 2017;17(1):716.

40. Douglas F, Clark J, Craig L, Campbell J, McNeill G. "It's a balance of just getting things right":mothers' views about pre-school childhood obesity and obesity prevention in Scotland. BMC Public Health. 2014;14(1):1009. 
41. Flores G, Maldonado J, Duran P. Making tortillas without lard: Latino parents' perspectives on healthy eating, physical activity, and weight-management strategies for overweight Latino children. Journal of the Academy of Nutrition and Dietetics. 2012;112(1):81-9.

42. Lora KR, Cheney M, Branscum P. Hispanic Mothers' Views of the Fathers' Role in Promoting Healthy Behaviors at Home: Focus Group Findings. Journal of the Academy of Nutrition and Dietetics. 2017;117(6):914-22.

43. Roth-Yousey L, Chu YL, Reicks M. A qualitative study to explore how parental expectations and rules influence beverage choices in early adolescence. J Nutr Educ Behav. 2012;44(6):644-52.

44. Berge JM, Trofholz A, Schulte A, Conger K, Neumark-Sztainer D. A Qualitative Investigation of Parents' Perspectives About Feeding Practices With Siblings Among Racially/Ethnically and Socioeconomically Diverse Households. Journal of Nutrition Education and Behavior. 2016;48(7):496-504.e1.

45. Blake CE, Fisher JO, Ganter C, Younginer N, Orloski A, Blaine RE, et al. A qualitative study of parents' perceptions and use of portion size strategies for preschool children's snacks. Appetite. 2015;88:17-23.

46. Johnson SL, Goodell LS, Williams K, Power TG, Hughes SO. Getting my child to eat the right amount. Mothers' considerations when deciding how much food to offer their child at a meal. Appetite. 2015;88:24-32.

47. Younginer NA, Blake CE, Davison KK, Blaine RE, Ganter C, Orloski A, et al. "What do you think of when I say the word 'snack'?" Towards a cohesive definition among low-income caregivers of preschool-age children. Appetite. 2016;98:35-40.

48. Jacquier EF, Gatrell A, Bingley A. "We don't snack": Attitudes and perceptions about eating in-between meals amongst caregivers of young children. Appetite. 2017;108:483-90.

49. Fay SH, Ferriday D, Hinton EC, Shakeshaft NG, Rogers PJ, Brunstrom JM. What determines real-world meal size? Evidence for pre-meal planning. Appetite. 2011;56(2):284-9.

50. Birch LL. Learning to Eat: Behavioral and Psychological Aspects. Nestle Nutrition Institute workshop series. 2016;85:125-34. 
51. Fulkerson JA, Neumark-Sztainer D, Story M, Gurvich O, Kubik MY, Garwick A, et al. The Healthy Home Offerings via the Mealtime Environment (HOME) Plus study: Design and methods. Contemporary clinical trials. 2014;38(1):59-68.

52. Small L, Lane H, Vaughan L, Melnyk B, McBurnett D. A systematic review of the evidence: the effects of portion size manipulation with children and portion education/training interventions on dietary intake with adults. Worldviews on evidence-based nursing. 2013;10(2):69-81.

53. Hausman NL, Borrero JC, Fisher A, Kahng S. Teaching young children to make accurate portion size estimations using a stimulus equivalence paradigm. Behavioral Interventions. 2017;32(2):121-32.

54. Savage JS, Fisher JO, Marini M, Birch LL. Serving smaller age-appropriate entree portions to children aged 3-5 y increases fruit and vegetable intake and reduces energy density and energy intake at lunch. Am J Clin Nutr. 2012;95(2):335-41.

55. Spill MK, Birch LL, Roe LS, Rolls BJ. Hiding vegetables to reduce energy density: an effective strategy to increase children's vegetable intake and reduce energy intake. The American Journal of Clinical Nutrition. 2011.

56. Leahy KE, Birch LL, Rolls BJ. Reducing the energy density of multiple meals decreases the energy intake of preschool-age children. Am J Clin Nutr. 2008;88(6):1459-68.

57. Leahy KE, Birch LL, Fisher JO, Rolls BJ. Reductions in Entrée Energy Density Increase Children's Vegetable Intake and Reduce Energy Intake. Obesity. 2008;16(7):1559-65.

58. Leahy KE, Birch LL, Rolls BJ. Reducing the energy density of an entree decreases children's energy intake at lunch. Journal of the American Dietetic Association. 2008;108(1):41-8.

59. Mack I, Sauer H, Weimer K, Dammann D, Zipfel S, Enck P, et al. Obese children and adolescents need increased gastric volumes in order to perceive satiety. Obesity. 2014;22(10):2123-5. 60. Lundahl A, Kidwell KM, Nelson TD. Parental Underestimates of Child Weight: A Metaanalysis. Pediatrics. 2014.

61. Sealy YM, Farmer GL. Parents' Stage of Change for Diet and Physical Activity: Influence on Childhood Obesity. Social work in health care. 2011;50(4):274-91. 
62. Torbahn G, Gellhaus I, Koch B, Von Kries R, Obermeier V, Holl RW, et al. Reduction of portion size and eating rate is associated with BMI-SDS reduction in overweight and obese children and adolescents: Results on eating and nutrition behaviour from the observational $\mathrm{KgAS}$ study. Obesity Facts. 2017;10(5):503-16.

63. Pomeranz JL, Miller DP. Policies to promote healthy portion sizes for children. Appetite. 2015;88:50-8.

64. Montagnese C, Santarpia L, Buonifacio M, Nardelli A, Caldara AR, Silvestri E, et al. European food-based dietary guidelines: a comparison and update. Nutrition (Burbank, Los Angeles County, Calif). 2015;31(7-8):908-15.

65. Department of Health. Healthy Food for Life - the Healthy Eating Guidelines and Food Pyramid 2016 [cited 2017 August 10]. Available from: http://www.healthyireland.ie/healthinitiatives/heg/.

66. U.S. Department of Health and Human Services and U.S. Department of Agriculture. 2015 2020 Dietary Guidelines for Americans. 8th Edition. December 2015. Available at https://health.gov/dietaryguidelines/2015/guidelines/.

67. National Health and Medical Research Council. Australian Dietary Guidelines. Canberra: National Health and Medical Research Council; 2013.

68. . U.S. Department of Health and Human Services and U.S. Department of Agriculture. 20152020 Dietary Guidelines for Americans. 8th Edition. December 2015. Available at http://health.gov/dietaryguidelines/2015/guidelines/. 


\section{Table and Figure Legends}

Box 1: SPIDER tool criteria for study eligibility (inclusion and exclusion)

Figure 1: PRISMA flow diagram of study inclusion and exclusion

Figure 2: MMAT quality appraisal criteria (quantitative studies)

Figure 3: MMAT quality appraisal criteria (qualitative studies)

Table 1A: Characteristics of included studies (quantitative studies)

Table 1B: Characteristics of included studies (qualitative studies) 


\begin{tabular}{|c|c|c|c|}
\hline $\begin{array}{l}\text { CRITERIA } \\
\text { (SPIDER) }\end{array}$ & INCLUSION & EXCLUSION & EXPLANATION / ELABORATION \\
\hline Sample & $\begin{array}{l}\text { Parents with at } \\
\text { least one child } \\
\text { aged } 2-12 \\
\text { years, residing } \\
\text { in developed } \\
\text { countries. }\end{array}$ & $\begin{array}{l}\text { Parents of children } \\
\text { with acute or } \\
\text { chronic illness. }\end{array}$ & $\begin{array}{l}\text { Residing countries were restricted to 'very high' } \\
\text { Human Development Index (i.e. } \mathrm{HDI} \geq 80)^{\mathrm{b}} \text {, as } \\
\text { findings will inform future public health guidance } \\
\text { in the Republic of Ireland and Northern Ireland } \\
\text { and parental portioning practices would likely be } \\
\text { influenced by the broader health and economic } \\
\text { context of a society. } \\
\text { Children with acute or chronic illness may require } \\
\text { medical nutrition therapy as part of their } \\
\text { treatment and/or management that may influence } \\
\text { the amounts of foods or beverages parents } \\
\text { portion for their child. }\end{array}$ \\
\hline $\begin{array}{l}\text { Phenomenon } \\
\text { of Interest }\end{array}$ & $\begin{array}{l}\text { Parental } \\
\text { portioning of } \\
\text { foods or } \\
\text { beverages for } \\
\text { their child. }\end{array}$ & $\mathrm{n} / \mathrm{a}$ & $\begin{array}{l}\text { Parental portioning refers to how parents portion } \\
\text { foods and beverages for their child including } \\
\text { amounts parents serve and amounts parents } \\
\text { make available to children from which they may } \\
\text { serve themselves. }\end{array}$ \\
\hline Design & None. & $\begin{array}{l}\text { Post-test data from } \\
\text { experimental } \\
\text { studies. }\end{array}$ & $\begin{array}{l}\text { Post-test data from experimental studies aimed at } \\
\text { modifying parental practices were excluded, as } \\
\text { this review aimed to understand existing practices. }\end{array}$ \\
\hline Evaluation & $\begin{array}{l}\text { Practices (and } \\
\text { factors } \\
\text { influencing } \\
\text { these practices, } \\
\text { e.g. opinions, } \\
\text { knowledge). }\end{array}$ & None. & $\begin{array}{l}\text { Factors influencing practices included a) measured } \\
\text { indicators demonstrated to modify parents' } \\
\text { portioning practices and, b) factors parents } \\
\text { themselves identified as influencing their } \\
\text { practices. Examples included parental knowledge, } \\
\text { attitudes or opinions on child portion size, or } \\
\text { demographic, socioeconomic or anthropometric } \\
\text { characteristics of the parent or child. }\end{array}$ \\
\hline $\begin{array}{l}\text { Research } \\
\text { type }\end{array}$ & $\begin{array}{l}\text { Quantitative, } \\
\text { qualitative and } \\
\text { mixed methods } \\
\text { research. }\end{array}$ & None. & \\
\hline $\begin{array}{l}\text { Other: article } \\
\text { type }\end{array}$ & $\begin{array}{l}\text { Peer-reviewed } \\
\text { original research } \\
\text { articles and } \\
\text { reviews. }\end{array}$ & $\begin{array}{l}\text { Articles without or } \\
\text { with limited results, } \\
\text { e.g. conference } \\
\text { abstracts, editorials } \\
\text { or commentaries } \\
\end{array}$ & $\begin{array}{l}\text { Reported results were required to synthesize the } \\
\text { evidence. In scoping searches, all relevant articles } \\
\text { identified were published in peer-reviewed } \\
\text { journals. }\end{array}$ \\
\hline $\begin{array}{l}\text { Other: } \\
\text { language }\end{array}$ & English & $\mathrm{n} / \mathrm{a}$ & $\begin{array}{l}\text { In scoping searches, we found no relevant articles } \\
\text { published in languages other than English. }\end{array}$ \\
\hline
\end{tabular}

${ }^{\text {a }}$ Studies where the majority of parents had children aged $2-12$ years were also included, e.g. children aged $1-5$ years or $3-13$ years.

b Selim Jahan, et al., Human Development Report 2016: Human Development for Everyone. 2016, United Nations Development Program (UNDP): Canada.

Plating up appropriate portion sizes for children 


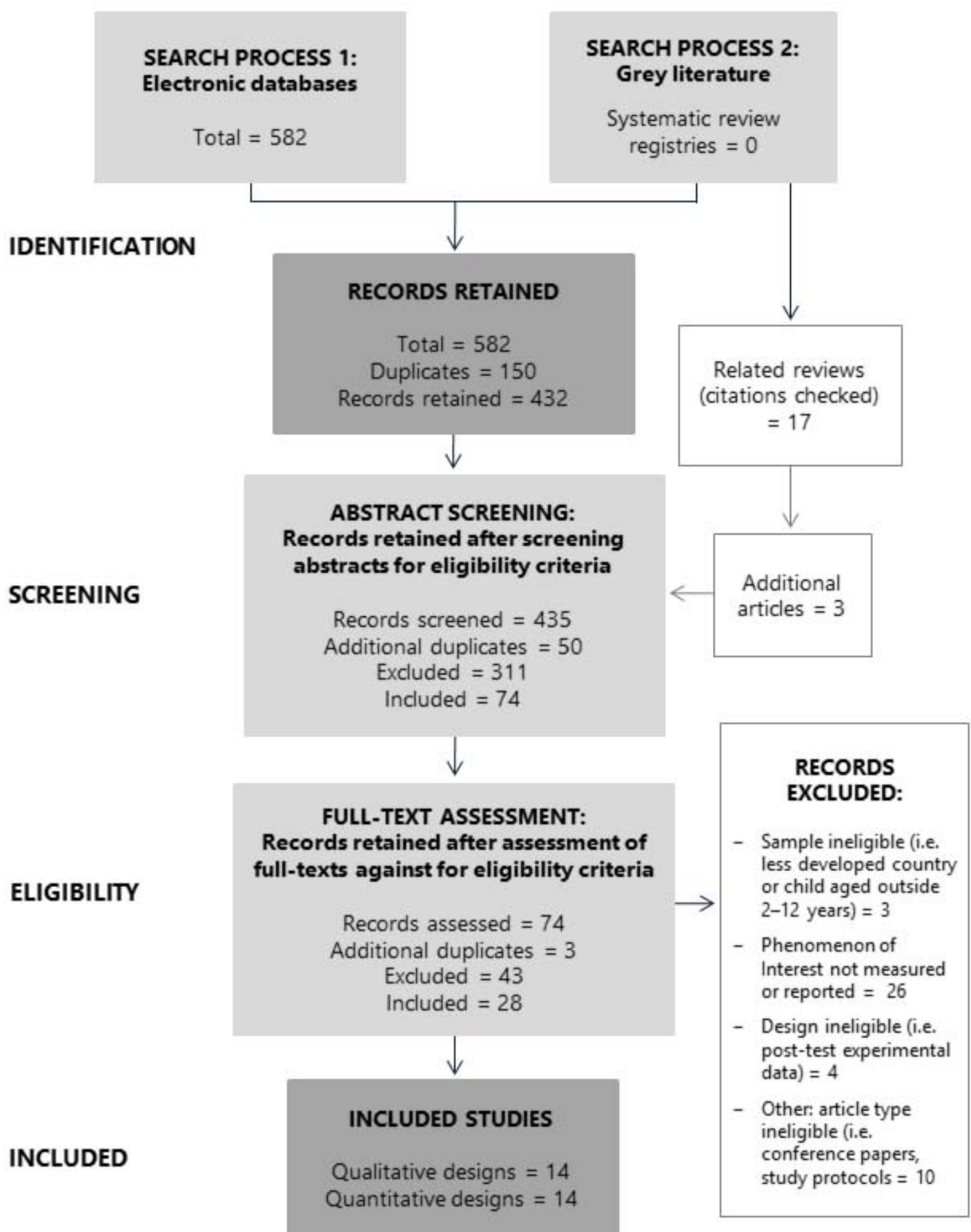

Plating up appropriate portion sizes for children 


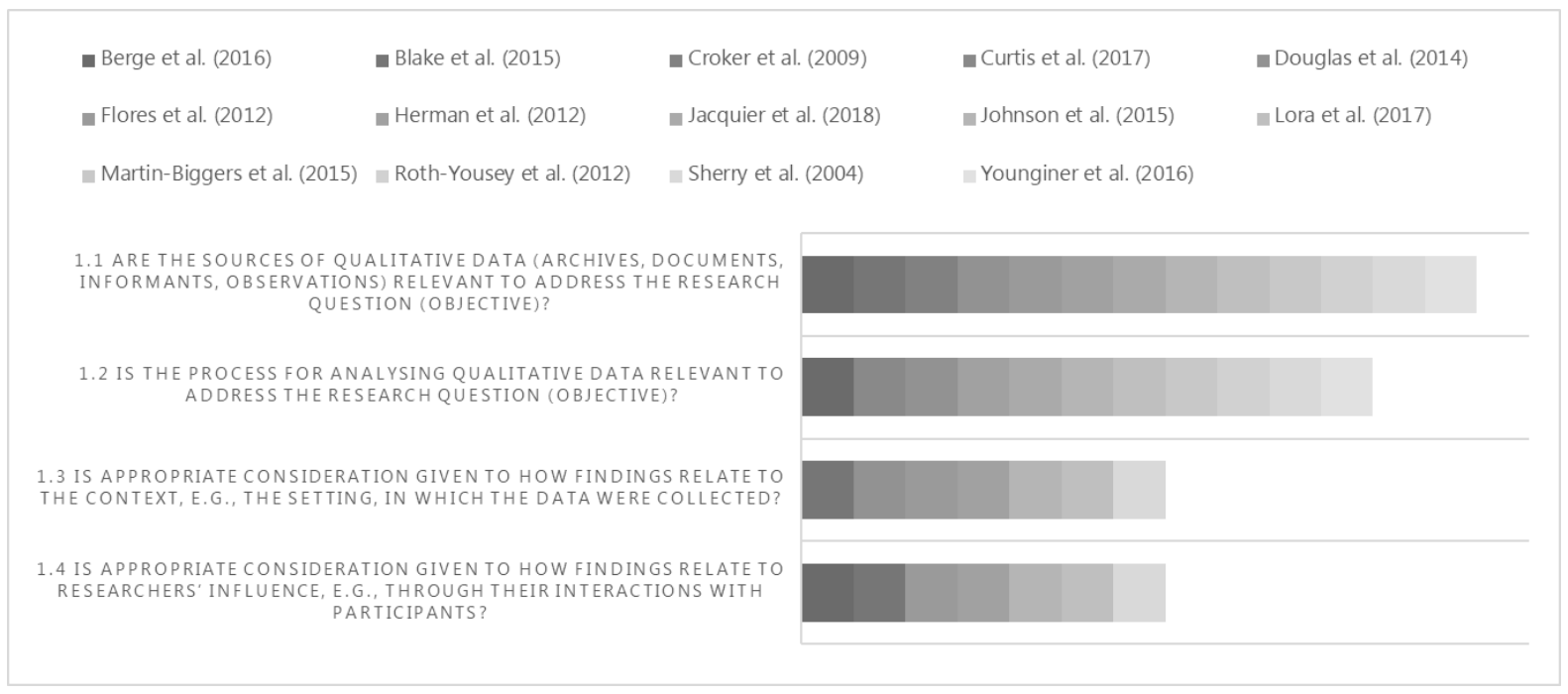

- Asante et al. (2009) Campbell et al. (2009) _ Dallacker et al. (2016) Edwards et al. (2017) Fulkerson et al. (2018)

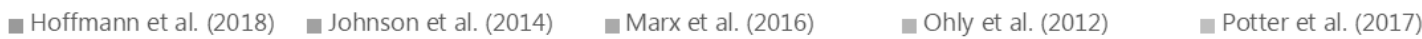

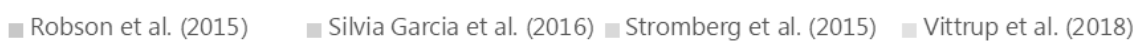

4.1. IS THE SAMPLING STRATEGYRELEVANT TO ADDRESS THE QUANTITATIVERESEARCH QUESTION(S)?

4.2. IS THE SAMPLEREPRESENTATIVE OF THE POPULATION UNDER STUDY?

4.3. ARE MEASUREMENTS APPROPRIATE (CLEAR ORIGIN, OR VALIDITY KNOWN, OR STANDARD INSTRUMENT)?

4.4. IS THERE AN ACCEPTABLERESPONSERATE ( $60 \%$ OR ABOVE)?

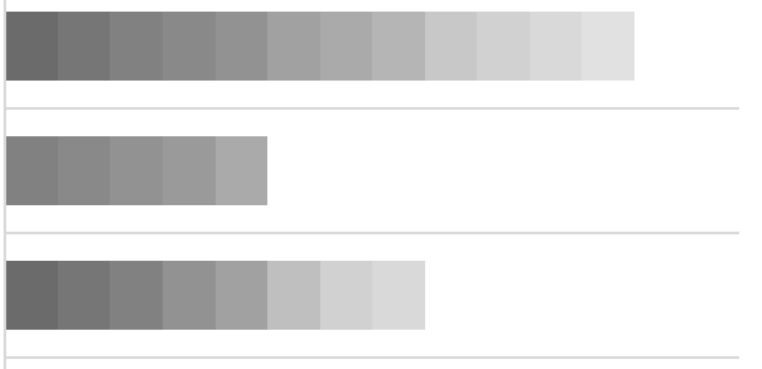




\begin{tabular}{|c|c|c|c|c|c|c|c|c|c|}
\hline \multirow{2}{*}{$\begin{array}{l}\text { Lead } \\
\text { Author } \\
\text { (Year) }\end{array}$} & \multirow[t]{2}{*}{ Research aim(s) } & \multicolumn{2}{|l|}{ Subjects } & \multirow[t]{2}{*}{ Setting } & \multirow{2}{*}{$\begin{array}{l}\text { Subject selection (exclusion } \\
\text { criteria) }\end{array}$} & \multirow[t]{2}{*}{ Study design } & \multicolumn{3}{|l|}{ Outcome(s) } \\
\hline & & $\mathbf{N}$ & Characteristics & & & & Outcome & Measurement & $\begin{array}{l}\text { Validity / } \\
\text { Reliability }\end{array}$ \\
\hline $\begin{array}{l}\text { Asante et } \\
\text { al. (2009) } \\
\text { (24) }\end{array}$ & $\begin{array}{l}\text { To inform the } \\
\text { design of a } \\
\text { multidisciplinary, } \\
\text { pediatric } \\
\text { overweight } \\
\text { prevention } \\
\text { program within a } \\
\text { primary care } \\
\text { setting by } \\
\text { describing (a) } \\
\text { prevalence of } \\
\text { overweight- } \\
\text { related behaviors, } \\
\text { (b) parents' } \\
\text { perceived } \\
\text { willingness to } \\
\text { change these } \\
\text { behaviors, and (c) } \\
\text { gaps in nutrition } \\
\text { and physical } \\
\text { activity promotion } \\
\text { in the practice. }\end{array}$ & $\begin{array}{l}\text { Parents } \\
\text { (child } \\
\text { aged 3- } \\
13 \text { years) } \\
=324\end{array}$ & $\begin{array}{l}\text { Country: US } \\
\text { Race/ethnicity/culture/language: } \\
\text { ethnicity, White: } 9 \% \text {, Black: } 55 \% \text {, } \\
\text { Hispanic: } 28 \% \text {, Asian: } 6 \% \text {, Other: } 3 \% \\
\text { Socioeconomic status, less than high } \\
\text { school attained: } 39 \% \\
\text { Weight status, overweight or obese: } \\
63 \% \\
\text { Child gender, Female } 44 \% \\
\text { Child age, Mean (SD) years: } 8.5 \text { (3.1) } \\
\text { Child weight status, mean (SD) BMI: } \\
19.6(5.2)\end{array}$ & $\begin{array}{l}\text { Urban } \\
\text { pediatric } \\
\text { primary care } \\
\text { clinic in } \\
\text { Boston, US. }\end{array}$ & $\begin{array}{l}\text { Parents attending a 'well-child' } \\
\text { care visit at the clinic between } \\
\text { July and August, } 2008 \text {, were } \\
\text { approached by research } \\
\text { assistants to complete a } \\
\text { questionnaire. Eligible parents } \\
\text { could be interviewed in English } \\
\text { or Spanish and the selected } \\
\text { child was free of any condition } \\
\text { restricting their diet or physical } \\
\text { activity. Of the } 330 \text { ( } 77 \%) \\
\text { agreeing, six were excluded as } \\
\text { the child was } \leq 5 \text { th BMI } \\
\text { percentile. }\end{array}$ & $\begin{array}{l}\text { Observational, } \\
\text { cross-sectional } \\
\text { using } \\
\text { quantitative } \\
\text { methods: } \\
\text { written } \\
\text { questionnaire }\end{array}$ & $\begin{array}{l}\text { Parental } \\
\text { perceived } \\
\text { willingness to } \\
\text { decrease } \\
\text { family } \\
\text { portion sizes } \\
\text { at meals. }\end{array}$ & $\begin{array}{l}\text { A } 58 \text {-item questionnaire using close-ended } \\
\text { questions. Response options for questions } \\
\text { on perceived willingness were: 'yes, we } \\
\text { plan to do it,' 'might do it,' and 'no, will } \\
\text { not do it' or 'already doing that'. } \\
\text { Weight and height were measured using } \\
\text { the clinic's scale and stadiometer by } \\
\text { trained clinical assistants. BMI percentiles } \\
\text { were based on } 2000 \text { CDC reference } \\
\text { values. }\end{array}$ & $\begin{array}{l}\text { Questions } \\
\text { assessing } \\
\text { perceived } \\
\text { willingness } \\
\text { to change } \\
\text { based on } \\
\text { Motivation } \\
\text { al } \\
\text { Interviewin } \\
\mathrm{g} \\
\text { techniques. }\end{array}$ \\
\hline $\begin{array}{l}\text { Campbell } \\
\text { et al. } \\
(2009)(25)\end{array}$ & $\begin{array}{l}\text { To explore } \\
\text { parents' (or } \\
\text { caregivers') } \\
\text { awareness of and } \\
\text { confidence in } \\
\text { adopting } \\
\text { recommendations } \\
\text { for childhood and } \\
\text { adolescent weight } \\
\text { control. }\end{array}$ & $\begin{array}{l}\text { Parents } \\
\text { (child } \\
\text { mean } \\
(\text { SD) age } \\
11.3(3.1) \\
\text { years) }= \\
193\end{array}$ & $\begin{array}{l}\text { Country, US } \\
\text { Socioeconomic status, Medicaid: } 47 \% \\
\text { Child gender, Female } 51 \% \\
\text { Child race/ethnicity/culture/language, } \\
\text { White: } 35 \% \text {, Black: } 17 \% \text {, Hispanic: } \\
34 \% \text {, Other: } 14 \% \\
\text { Child weight status, mean (SD) BMI } \\
\text { percentile: } 99 \text { (1.03) }\end{array}$ & $\begin{array}{l}\text { Nemours } \\
\text { Healthy } \\
\text { Choices } \\
\text { Clinic (a } \\
\text { multi- } \\
\text { disciplinary } \\
\text { treatment } \\
\text { center). }\end{array}$ & $\begin{array}{l}\text { Families attending the clinic } \\
\text { were invited to complete a } \\
\text { survey prior to the initiation of } \\
\text { treatment. Surveys with more } \\
\text { than } 10 \% \text { of items unanswered } \\
\text { were excluded, although } \\
\text { characteristics of excluded } \\
\text { participants were comparable to } \\
\text { those included }(\mathrm{N}=193) .\end{array}$ & $\begin{array}{l}\text { Observational, } \\
\text { cross-sectional } \\
\text { using } \\
\text { quantitative } \\
\text { methods: } \\
\text { written } \\
\text { questionnaire }\end{array}$ & $\begin{array}{l}\text { Perceived } \\
\text { importance of } \\
\text { and concern } \\
\text { about specific } \\
\text { child and } \\
\text { adolescent } \\
\text { lifestyle } \\
\text { behaviors. } \\
\text { Confidence in } \\
\text { ability and } \\
\text { readiness to } \\
\text { change the } \\
\text { eating habits } \\
\text { of their child } \\
\text { or adolescent. }\end{array}$ & $\begin{array}{l}\text { Questionnaire items included quantitative } \\
\text { items assessing confidence in ability to } \\
\text { change diet and physical activity behaviors } \\
\text { of their child or adolescent and qualitative } \\
\text { items that were coded and ranked } \\
\text { categorically to assess the frequency at } \\
\text { which parents identified the studied health } \\
\text { behaviors as important components of } \\
\text { healthy living. }\end{array}$ & $\begin{array}{l}\text { Survey } \\
\text { items based } \\
\text { on } \\
\text { motivationa } \\
1 \\
\text { interviewin } \\
\mathrm{g} \\
\text { principles. } \\
\text { Inter-coder } \\
\text { reliability } \\
\text { of coded } \\
\text { behaviors } \\
\text { was strong } \\
(\mathrm{K}=0.98, \\
P<.001) \text {. }\end{array}$ \\
\hline $\begin{array}{l}\text { Dallacker } \\
\text { et al. } \\
\text { (2016) (35) }\end{array}$ & $\begin{array}{l}\text { To examine the } \\
\text { relationship } \\
\text { between parental } \\
\text { numeracy and } \\
\text { children's BMI z- }\end{array}$ & $\begin{array}{l}\text { Parents } \\
\text { (child } \\
\text { aged 6- } \\
12 \text { years) } \\
=320\end{array}$ & $\begin{array}{l}\text { Country, Germany } \\
\text { Gender, Female: } 86.2 \% \\
\text { Age, } 18-40 \text { years: } 52.7 \% \\
\text { Socioeconomic status, secondary } \\
\text { education attained: } 75.6 \%\end{array}$ & $\begin{array}{l}\text { Family home } \\
\text { of the parent- } \\
\text { child dyad. }\end{array}$ & $\begin{array}{l}\text { Parents identifying as the } \\
\text { nutritional gatekeepers, with } \\
\text { one or more children aged 6-12 } \\
\text { years, were recruited by a } \\
\text { commercial market research }\end{array}$ & $\begin{array}{l}\text { Observational, } \\
\text { cross-sectional } \\
\text { using } \\
\text { quantitative } \\
\text { methods: }\end{array}$ & $\begin{array}{l}\text { Parental } \\
\text { portion size } \\
\text { estimation } \\
\text { skills }\end{array}$ & $\begin{array}{l}\text { Parents were presented with } 15 \text { images } \\
\text { each of five typical foods for children (e.g. } \\
\text { cornflakes), in one tablespoon portion size } \\
\text { increments. Parents were asked: 'The } \\
\text { recommended amount for children aged }\end{array}$ & $\begin{array}{l}\text { Picture sets } \\
\text { were pilot } \\
\text { tested with } \\
\text { parents } \\
\text { demonstrati }\end{array}$ \\
\hline
\end{tabular}

Plating up appropriate portion sizes for children 


\begin{tabular}{|c|c|c|c|c|c|c|c|c|c|}
\hline \multirow{2}{*}{$\begin{array}{l}\text { Lead } \\
\text { Author } \\
\text { (Year) }\end{array}$} & \multirow[t]{2}{*}{ Research aim(s) } & \multicolumn{2}{|l|}{ Subjects } & \multirow[t]{2}{*}{ Setting } & \multirow{2}{*}{$\begin{array}{l}\text { Subject selection (exclusion } \\
\text { criteria) }\end{array}$} & \multirow[t]{2}{*}{ Study design } & \multicolumn{3}{|l|}{ Outcome(s) } \\
\hline & & $\mathbf{N}$ & Characteristics & & & & Outcome & Measurement & $\begin{array}{l}\text { Validity / } \\
\text { Reliability }\end{array}$ \\
\hline & $\begin{array}{l}\text { scores and } \\
\text { whether weight- } \\
\text { related numerical } \\
\text { information } \\
\text { processing skills } \\
\text { (including portion } \\
\text { size estimation } \\
\text { skills) mediated } \\
\text { this relationship. }\end{array}$ & & $\begin{array}{l}\text { Weight status, overweight or obese: } \\
\text { 48\% } \\
\text { Child gender, Female: } 54.8 \% \\
\text { Child age, years: } 6(16.3 \%), 7(11.9 \%) \text {, } \\
8(11.3 \%), 9(17.2 \%), 10(12.8 \%), 11 \\
(14.1 \%), 12(16.5 \%) \\
\text { Child weight status, healthy weight: } \\
\text { child aged } 6 \text { years: } 65.4 \%, 7-10 \text { years: } \\
61.2 \%, 11-13 \text { years: } 79.6 \% \text {. }\end{array}$ & & $\begin{array}{l}\text { company. Of the } 326 \text { parent- } \\
\text { child dyads recruited, five were } \\
\text { excluded due to omissions or } \\
\text { measurement errors in height or } \\
\text { weight data and one due to a } \\
\text { data entry error. }\end{array}$ & $\begin{array}{l}\text { computer- } \\
\text { assisted face-to- } \\
\text { face survey and } \\
\text { anthropometric } \\
\text { measurements }\end{array}$ & & $\begin{array}{l}{[\mathrm{XX}] \text { years is [YYY] grams. Among the }} \\
\text { following pictures, please choose the one } \\
\text { that shows the recommended amount.' } \\
\text { Parents could scroll through the pictures } \\
\text { and select their estimate of the } \\
\text { recommended amount. A portion size } \\
\text { estimation score (PSE) was created based } \\
\text { on the deviation between the parent's } \\
\text { estimate and recommended amount. } \\
\text { Numeracy skills assessed using a validated } \\
\text { eight-item scale. A higher score reflects a } \\
\text { greater number of correct responses. }\end{array}$ & $\begin{array}{l}\text { ng good } \\
\text { predictive } \\
\text { validity }(\mathrm{r}= \\
0.60-0.80) \\
\text { and test- } \\
\text { retest } \\
\text { reliability ( } \mathrm{r} \\
>0.80) \text {. }\end{array}$ \\
\hline $\begin{array}{l}\text { Edwards } \\
\text { et al. } \\
\text { (2017) (36) }\end{array}$ & $\begin{array}{l}\text { To assess parents' } \\
\text { reported child } \\
\text { eating and activity } \\
\text { behaviors and } \\
\text { selected goals for } \\
\text { the Fitwits } \\
\text { intervention. }\end{array}$ & $\begin{array}{l}\text { Parents } \\
\text { (child } \\
\text { aged } 9- \\
12 \text { years) } \\
=140\end{array}$ & $\begin{array}{l}\text { Country, US } \\
\text { Gender, Female: } 79 \% \\
\text { Socioeconomic status, Medicaid: } 77 \% \\
\text { Child race/ethnicity/culture/language, } \\
\text { Black/African American: } 70 \% \text {, White: } \\
15 \%,>1 \text { race: } 13 \% \text {, Asian: } 2 \% \\
\text { Child weight status, overweight or } \\
\text { obese: } 53 \%\end{array}$ & $\begin{array}{l}\text { Urban family } \\
\text { health centers } \\
(\mathrm{n}=3) \text { in } \\
\text { western } \\
\text { Pennsylvania. }\end{array}$ & $\begin{array}{l}\text { The research team delivered } \\
\text { training to reception and } \\
\text { nursing staff and distributed } \\
\text { printed pages to staff and } \\
\text { patients outlining the study } \\
\text { eligibility criteria (child aged } \\
\text { 9-12 years, attending a well- } \\
\text { child scheduled visit with a } \\
\text { parent/guardian in attendance). }\end{array}$ & $\begin{array}{l}\text { Experimental, } \\
\text { pre-post using } \\
\text { quantitative } \\
\text { methods: } \\
\text { written } \\
\text { questionnaire } \\
\text { (pre- and post- } \\
\text { intervention), } \\
\text { anthropometric } \\
\text { measurements }\end{array}$ & $\begin{array}{l}\text { Parental } \\
\text { perceived } \\
\text { adequacy of } \\
\text { their child's } \\
\text { portion sizes } \\
\text { (pre- } \\
\text { intervention). }\end{array}$ & $\begin{array}{l}\text { The child behavior survey was developed } \\
\text { based on questions used in existing } \\
\text { published tools. In this survey, parents } \\
\text { were asked to respond to the question 'my } \\
\text { child eats a portion size of food at each } \\
\text { meal that is... 'too little', 'about right' or } \\
\text { 'too much'.' }\end{array}$ & $\begin{array}{l}\text { None for } \\
\text { this specific } \\
\text { question. }\end{array}$ \\
\hline $\begin{array}{l}\text { Fulkerson } \\
\text { et al. } \\
\text { (2018) (37) }\end{array}$ & $\begin{array}{l}\text { To describe } \\
\text { family home food } \\
\text { environment and } \\
\text { nutrition-related } \\
\text { parent and child } \\
\text { outcomes of a } \\
\text { family meals } \\
\text { childhood obesity } \\
\text { prevention } \\
\text { program. }\end{array}$ & $\begin{array}{l}\text { Primary } \\
\text { meal- } \\
\text { preparing } \\
\text { parents } \\
\text { (child } \\
\text { aged } 8- \\
12 \text { years) } \\
=160\end{array}$ & $\begin{array}{l}\text { Country, US } \\
\text { Gender, Female: } 95 \% \\
\text { Age, mean (SD) years: } 41.3 \text { (7.7) } \\
\text { Race/ethnicity/culture/language, White: } \\
77 \% \text {, Black: } 15 \% \text {, Other: } 8 \% \\
\text { Socioeconomic status, Economic } \\
\text { assistance received: } 39 \% \text {, Bachelor } \\
\text { degree or higher: } 59 \% \\
\text { Weight status, overweight or obese: } \\
61 \% \\
\text { Child age, mean (SD) years: } 10.3 \text { (1.4) } \\
\text { Child gender, Female: } 47 \% \\
\text { Child race/ethnicity/culture/language, } \\
\text { White: } 68 \% \text {, Black: } 18 \%, \text { Other: } 14 \% \\
\text { Child weight status, BMI } \geq 85^{\text {th }} \\
\text { percentile: } 44 \%\end{array}$ & $\begin{array}{l}\text { Participants' } \\
\text { homes or } \\
\text { community } \\
\text { centers in the } \\
\text { Minneapolis/ } \\
\text { St Paul, MN, } \\
\text { metropolitan } \\
\text { area. }\end{array}$ & $\begin{array}{l}\text { Parents recruited from } \\
\text { community centers via flyers, } \\
\text { e-mails, and in-person } \\
\text { presentations/ } \\
\text { discussions. Eligible children } \\
\text { were }>50^{\text {th }} \text { BMI-for-age } \\
\text { percentile, lived mostly with } \\
\text { participating parent and were } \\
\text { free of medical conditions or } \\
\text { limitations prohibiting their } \\
\text { participation. }\end{array}$ & $\begin{array}{l}\text { Experimental, } \\
\text { pre-post using } \\
\text { quantitative } \\
\text { methods: } \\
\text { written } \\
\text { questionnaire } \\
\text { (pre- and post- } \\
\text { intervention) }\end{array}$ & $\begin{array}{l}\text { Parental self- } \\
\text { efficacy for } \\
\text { identifying } \\
\text { appropriate } \\
\text { portion sizes } \\
\text { (for their } \\
\text { child and } \\
\text { others). }\end{array}$ & $\begin{array}{l}\text { Self-efficacy assessed by four items e.g. 'I } \\
\text { am confident that I know appropriate } \\
\text { portion sizes for my child's meal', and 'I } \\
\text { am } \\
\text { confident that I can estimate recommended } \\
\text { serving sizes for many foods'. Possible } \\
\text { scores across the four items ranged from } 4 \\
\text { to } 16 \text {. }\end{array}$ & $\begin{array}{l}\text { Internal } \\
\text { consistency } \\
\text { of self- } \\
\text { efficacy } \\
\text { scale (4- } \\
\text { items) was } \\
\alpha=.84 \text {. }\end{array}$ \\
\hline $\begin{array}{l}\text { Hoffmann } \\
\text { et al. } \\
\text { (2018) (28) }\end{array}$ & $\begin{array}{l}\text { To examine } \\
\text { differences in } \\
\text { children's intake }\end{array}$ & $\begin{array}{l}\text { Mothers } \\
\text { (child } \\
\text { aged } 7 \text { - }\end{array}$ & $\begin{array}{l}\text { Country, US } \\
\text { Age, mean (SD) years: } 34.2(6.8)\end{array}$ & $\begin{array}{l}\text { Setting } \\
\text { unclear. }\end{array}$ & $\begin{array}{l}\text { Mothers recruited via } \\
\text { Amazon's Mechanical Turk } \\
\text { platform. Eligible mothers had }\end{array}$ & $\begin{array}{l}\text { Observational, } \\
\text { cross-sectional } \\
\text { using }\end{array}$ & $\begin{array}{l}\text { Maternal } \\
\text { reported } \\
\text { frequency of }\end{array}$ & $\begin{array}{l}\text { Mothers were asked whether their child } \\
\text { helps themselves to food on their own for }\end{array}$ & $\begin{array}{l}\text { None for } \\
\text { this specific } \\
\text { question. }\end{array}$ \\
\hline
\end{tabular}

Plating up appropriate portion sizes for children 


\begin{tabular}{|c|c|c|c|c|c|c|c|c|c|}
\hline \multirow{2}{*}{$\begin{array}{l}\text { Lead } \\
\text { Author } \\
\text { (Year) }\end{array}$} & \multirow[t]{2}{*}{ Research aim(s) } & \multicolumn{2}{|l|}{ Subjects } & \multirow[t]{2}{*}{ Setting } & \multirow{2}{*}{$\begin{array}{l}\text { Subject selection (exclusion } \\
\text { criteria) }\end{array}$} & \multirow[t]{2}{*}{ Study design } & \multicolumn{3}{|l|}{ Outcome(s) } \\
\hline & & $\mathbf{N}$ & Characteristics & & & & Outcome & Measurement & $\begin{array}{l}\text { Validity / } \\
\text { Reliability }\end{array}$ \\
\hline & $\begin{array}{l}\text { (frequency and } \\
\text { portion sizes) on } \\
\text { weekdays and } \\
\text { weekend days, as } \\
\text { well as mothers' } \\
\text { perceptions of } \\
\text { intake and their } \\
\text { feeding goals. }\end{array}$ & $\begin{array}{l}11 \text { years) } \\
=192\end{array}$ & $\begin{array}{l}\text { Race/ethnicity/culture/language, } \\
\text { Caucasian: } 76 \% \\
\text { Socioeconomic status, some college } \\
\text { education: } 88 \% \text {, employed: } 43 \% \text {, annual } \\
\text { household income > } \$ 55,000: 52 \% \\
\text { Weight status, overweight or obese: } \\
49 \% \\
\text { Child age, mean (SD) years: } 8.7 \text { (1.4) }\end{array}$ & & $\begin{array}{l}\text { a child aged between } 7-11 \\
\text { years living in a two-parent } \\
\text { household and were fluent in } \\
\text { English. }\end{array}$ & $\begin{array}{l}\text { quantitative } \\
\text { methods: online } \\
\text { questionnaire }\end{array}$ & $\begin{array}{l}\text { child self- } \\
\text { serving for } \\
\text { meals and } \\
\text { snacks. }\end{array}$ & $\begin{array}{l}\text { meals and snacks on weekdays and } \\
\text { weekend days. }\end{array}$ & \\
\hline $\begin{array}{l}\text { Johnson et } \\
\text { al. (2014) } \\
\text { (34) }\end{array}$ & $\begin{array}{l}\text { To assess whether } \\
\text { the amounts } \\
\text { parents serve to } \\
\text { children at meals } \\
\text { are related to the } \\
\text { amounts they } \\
\text { serve themselves. }\end{array}$ & 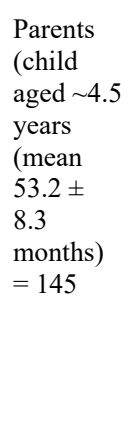 & $\begin{array}{l}\text { Country, US } \\
\text { Race/ethnicity/culture/language, } \\
\text { Hispanic/Latino: } 56.6 \% \text {, African } \\
\text { American: } 39.3 \% \\
\text { Socioeconomic status, high school or } \\
\text { less: } 52.4 \% \text {, employed: } 53.1 \% \\
\text { Marital status, married: } 39.3 \% \\
\text { Weight status, overweight or obese: } \\
77.9 \% \\
\text { Child weight status, }<85 \text { th percentile: } \\
57.3 \%\end{array}$ & $\begin{array}{l}\text { Participant's } \\
\text { family home. }\end{array}$ & $\begin{array}{l}\text { Parents were recruited from } 33 \\
\text { Head Start centers in three } \\
\text { districts of Houston, Texas } \\
\text { during child pick-up / drop-off } \\
\text { times and Head Start parent } \\
\text { meetings. Interested parents ( } \mathrm{n} \\
=275 \text { ) were informed on the } \\
\text { study procedures, of which } 145 \\
\text { parents }(\sim 6 \%) \text { consented for } \\
\text { themselves and their children to } \\
\text { participate out of an initial } \\
\sim 2500 \text { eligible families from } \\
\text { the Head Start centers. }\end{array}$ & $\begin{array}{l}\text { Observational, } \\
\text { cross-sectional } \\
\text { using } \\
\text { quantitative } \\
\text { methods: } \\
\text { written } \\
\text { questionnaire, } \\
\text { home meal } \\
\text { portioning } \\
\text { observation, } \\
\text { anthropometric } \\
\text { measurements }\end{array}$ & $\begin{array}{l}\text { Amounts of } \\
\text { food parent } \\
\text { served to their } \\
\text { child(ren) and } \\
\text { amounts } \\
\text { served to } \\
\text { themselves. }\end{array}$ & $\begin{array}{l}\text { For the home meal observation, all food } \\
\text { placed onto the children's dinner plates by } \\
\text { the parent was measured using a } \\
\text { standardized digital photography method. } \\
\text { Second helpings were noted and } \\
\text { estimated. Food plate waste was measured } \\
\text { on a digital scale to the nearest } 0.1 \mathrm{~g} \text {. } \\
\text { Child weight and height was measured } \\
\text { twice by trained staff using a standard } \\
\text { protocol to the nearest } 0.1 \mathrm{~kg} \text { and } 0.1 \mathrm{~cm} \text {, } \\
\text { respectively, and the average taken. Child } \\
\text { BMI was based on } 2000 \mathrm{CDC} \text { reference } \\
\text { values. }\end{array}$ & $\begin{array}{l}\text { Digital } \\
\text { photograph } \\
\text { y method } \\
\text { previously } \\
\text { validated } \\
\text { with proven } \\
\text { reliability. }\end{array}$ \\
\hline $\begin{array}{l}\text { Marx et al. } \\
(2016)(26)\end{array}$ & $\begin{array}{l}\text { To examine } \\
\text { preschoolers' and } \\
\text { their parents' } \\
\text { characterizations } \\
\text { of eating episodes } \\
\text { based on cues (i.e. } \\
\text { time, portions } \\
\text { size, preparation, } \\
\text { content and } \\
\text { emotion) used for } \\
\text { defining these } \\
\text { occasions as a } \\
\text { meal or a snack. }\end{array}$ & $\begin{array}{l}\text { Parents } \\
\text { (child } \\
\text { aged 4-6 } \\
\text { years) }= \\
26\end{array}$ & $\begin{array}{l}\text { Country, US } \\
\text { Gender, Female: } 85 \% \\
\text { Age, mean (SD) years: } 35.1 \text { (6.6) } \\
\text { Race/ethnicity/culture/language, } \\
\text { Caucasian } 92 \% \\
\text { Weight status, BMI: mean (SD) } 27.1 \\
\text { (5.1) } \mathrm{kg} / \mathrm{m} 2 \\
\text { Child age, mean (SD) years: } 4.5(0.6) \\
\text { Child gender, Female: } 47 \% \\
\text { Child weight status, BMI percentile: } \\
75.5 \text { (24.3) }\end{array}$ & $\begin{array}{l}\text { Parents } \\
\text { completed } \\
\text { questionnaire } \\
\text { online. }\end{array}$ & $\begin{array}{l}\text { Invitation letters were } \\
\text { distributed to parents via } \\
\text { participating day care centers } \\
(\mathrm{n}=6) \text { in Northwest Ohio. } \\
\text { Eligible children were aged 4-6 } \\
\text { years and familiar with the } \\
\text { terminology (i.e. 'I'm going to } \\
\text { eat a meal' and 'It's time for a } \\
\text { snack'). }\end{array}$ & $\begin{array}{l}\text { Observational, } \\
\text { cross-sectional } \\
\text { using } \\
\text { quantitative } \\
\text { methods: online } \\
\text { questionnaire }\end{array}$ & $\begin{array}{l}\text { Parental } \\
\text { classification } \\
\text { of portion- } \\
\text { related cues } \\
\text { as a meal or } \\
\text { snack. }\end{array}$ & $\begin{array}{l}\text { Parents were asked to classify four } \\
\text { portion-related cues (a large portion, a } \\
\text { small portion, everything is served and as } \\
\text { much as someone wants) as a 'meal', } \\
\text { 'snack', 'either (i.e. meal or snack)' or } \\
\text { 'neither'. }\end{array}$ & $\begin{array}{l}\text { None } \\
\text { reported. }\end{array}$ \\
\hline $\begin{array}{l}\text { Ohly et al. } \\
\text { (2013) (27) }\end{array}$ & $\begin{array}{l}\text { To explore factors } \\
\text { influencing } \\
\text { parents' food } \\
\text { choices for their } \\
\text { children and their } \\
\text { views on support } \\
\text { for healthy eating. }\end{array}$ & $\begin{array}{l}\text { Parents } \\
\text { (child } \\
\text { aged 2-5 } \\
\text { years) }= \\
261\end{array}$ & $\begin{array}{l}\text { Country, England } \\
\text { Gender, Female } 94.2 \% \\
\text { Age, mean (SD) years: } 33.5 \text { ( } 6.6) \\
\text { Race/ethnicity/culture/language, White } \\
\text { British } 75.3 \% \\
\text { Socioeconomic status, employed: }\end{array}$ & $\begin{array}{l}\text { Children's } \\
\text { centers }(\mathrm{n}= \\
15) \text { in } \\
\text { Cornwall } \\
\text { (rural; } \mathrm{n}=10) \\
\text { and Islington }\end{array}$ & $\begin{array}{l}\text { Researchers visited child and } \\
\text { parent play sessions at } \\
\text { children's centers and invited } \\
\text { parents with a child aged } 2-5 \\
\text { years to complete the } \\
\text { questionnaire. Staff members } \\
\text { were given additional copies of }\end{array}$ & $\begin{array}{l}\text { Observational, } \\
\text { cross-sectional } \\
\text { using } \\
\text { quantitative } \\
\text { methods: } \\
\text { written } \\
\text { questionnaire }\end{array}$ & $\begin{array}{l}\text { Parental } \\
\text { perceived } \\
\text { usefulness of } \\
\text { support for } \\
\text { learning } \\
\text { about } \\
\text { appropriate }\end{array}$ & $\begin{array}{l}\text { Parents were asked 'which of the following } \\
\text { would you find useful at your children's } \\
\text { center?' with response options 'very useful, } \\
\text { 'moderately useful' or 'not useful'. One } \\
\text { item was 'learning about appropriate } \\
\text { portion sizes for children'. }\end{array}$ & $\begin{array}{l}\text { Questionnai } \\
\text { re items } \\
\text { developed } \\
\text { based on } \\
\text { validated } \\
\text { items from }\end{array}$ \\
\hline
\end{tabular}

Plating up appropriate portion sizes for children 


\begin{tabular}{|c|c|c|c|c|c|c|c|c|c|}
\hline \multirow{2}{*}{$\begin{array}{l}\text { Lead } \\
\text { Author } \\
\text { (Year) }\end{array}$} & \multirow[t]{2}{*}{ Research aim(s) } & \multicolumn{2}{|l|}{ Subjects } & \multirow[t]{2}{*}{ Setting } & \multirow{2}{*}{$\begin{array}{l}\text { Subject selection (exclusion } \\
\text { criteria) }\end{array}$} & \multirow[t]{2}{*}{ Study design } & \multicolumn{3}{|l|}{ Outcome(s) } \\
\hline & & $\mathbf{N}$ & Characteristics & & & & Outcome & Measurement & $\begin{array}{l}\text { Validity / } \\
\text { Reliability }\end{array}$ \\
\hline & & & $\begin{array}{l}35.2 \% \text {, level of education: low } 31.6 \% \text {, } \\
\text { medium } 36.8 \% \text {, high } 31.6 \% \\
\text { Marital status, married/cohabiting: } \\
77.6 \%\end{array}$ & $\begin{array}{l}\text { (urban; } \mathrm{n}= \\
5 \text { ). }\end{array}$ & $\begin{array}{l}\text { the questionnaire to distribute } \\
\text { to parents at other sessions. Of } \\
\text { all questionnaires distributed, } \\
\text { approximately } 57 \%(\mathrm{n}=261) \\
\text { were completed by parents. }\end{array}$ & & $\begin{array}{l}\text { portion sizes } \\
\text { for children. }\end{array}$ & & $\begin{array}{l}\text { existing } \\
\text { surveys. }\end{array}$ \\
\hline $\begin{array}{l}\text { Potter et } \\
\text { al. (2017) } \\
\text { (30) }\end{array}$ & $\begin{array}{l}\text { To explore the } \\
\text { extent to which a } \\
\text { child's BMI is } \\
\text { predicted by their } \\
\text { parent's beliefs } \\
\text { about the child's } \\
\text { ideal and } \\
\text { maximum portion } \\
\text { size and/or by the } \\
\text { child's own } \\
\text { beliefs. }\end{array}$ & $\begin{array}{l}\text { Parents } \\
\text { (child } \\
\text { aged 5- } \\
11 \text { years) } \\
=198\end{array}$ & $\begin{array}{l}\text { Country, England } \\
\text { Socioeconomic status, employed: } 74 \% \\
\text { (parents with BMI }<25 \mathrm{~kg} / \mathrm{m} 2 \text { ) or } 84 \% \\
\text { (parents with BMI } \geq 25 \mathrm{~kg} / \mathrm{m} 2 \text { ). } \\
\text { Marital status, married } / \text { living with } \\
\text { partner: } 76 \% \text { (parents with BMI }< \\
25 \mathrm{~kg} / \mathrm{m}^{2} \text { ) to } 79 \% \text { (parents with BMI } \geq \\
25 \mathrm{~kg} / \mathrm{m}^{2} \text { ). } \\
\text { Weight status, overweight or obese: } \\
59.5 \% \\
\text { Child weight status, }<85^{\text {th }} \text { percentile: } \\
52.1 \%\end{array}$ & $\begin{array}{l}\text { Parents were } \\
\text { assessed at } \\
\text { their home (or } \\
\text { a testing } \\
\text { booth for } \\
\text { those } \\
\text { recruited at } \\
\text { the science } \\
\text { center). }\end{array}$ & $\begin{array}{l}\text { Parents were recruited from an } \\
\text { existing randomized trial }(\mathrm{n}= \\
69) \text { and an opportunity sample } \\
\text { from a local interactive science } \\
\text { center in Bristol }(\mathrm{n}=148) \text {. } \\
\text { Eligible parents had an } \\
\text { English-speaking child aged 5- } \\
11 \text { years, free of food allergies } \\
\text { or intolerances and not } \\
\text { following a vegetarian or vegan } \\
\text { diet. Of the } 217 \text { recruited } \\
\text { parents, } 19 \text { were excluded due } \\
\text { to learning disability, child with } \\
\text { a vegetarian or vegan parent, } \\
\text { and missing date of birth. }\end{array}$ & $\begin{array}{l}\text { Observational, } \\
\text { cross-sectional } \\
\text { using } \\
\text { quantitative } \\
\text { methods: } \\
\text { written } \\
\text { questionnaire, } \\
\text { anthropometric } \\
\text { measurements, } \\
\text { and visual } \\
\text { portion size } \\
\text { estimation task }\end{array}$ & $\begin{array}{l}\text { Parents' ideal } \\
\text { and } \\
\text { maximum } \\
\text { tolerated } \\
\text { estimated } \\
\text { portion sizes } \\
\text { for their child }\end{array}$ & $\begin{array}{l}\text { Visual portion size estimation task: } \\
\text { Parents were shown an image of a main } \\
\text { meal and asked to estimate the portion size } \\
\text { in response to the question: 'Imagine your } \\
\text { child is going to eat this food for dinner } \\
\text { and no other food is available. What } \\
\text { would be your child's perfect amount for } \\
\text { dinner?', and then again in response to: } \\
\text { 'Imagine your child is going to eat this } \\
\text { food for dinner and no other food is } \\
\text { available. What would be the most that } \\
\text { your child could eat for dinner?' Pictured } \\
\text { meals included chicken, chips (fries) and } \\
\text { baked beans; chicken curry with rice; } \\
\text { spaghetti Bolognese; lasagna and peas; } \\
\text { macaroni and cheese; sausage, mashed } \\
\text { potatoes and peas; and pizza and chips } \\
\text { (fries). Parents could scroll through } 50 \\
\text { meal images to increase or decrease the } \\
\text { portion size (20-kcal portion increment per } \\
\text { image). Child and parent weight and } \\
\text { height were measured using a digital scale } \\
\text { to the nearest } 0.1 \mathrm{~kg} \text { and a stadiometer to } \\
\text { the nearest millimeter, respectively. }\end{array}$ & $\begin{array}{l}\text { Yes. Visual } \\
\text { portion size } \\
\text { estimation } \\
\text { task based } \\
\text { on } \\
\text { previously } \\
\text { validated } \\
\text { method. }\end{array}$ \\
\hline $\begin{array}{l}\text { Robson et } \\
\text { al. (2016) } \\
\text { (31) }\end{array}$ & $\begin{array}{l}\text { To understand } \\
\text { barriers and } \\
\text { facilitators to } \\
\text { families eating } \\
\text { convenience foods } \\
\text { (authors also } \\
\text { collected data on } \\
\text { parents' } \\
\text { perceptions of } \\
\text { portions to } \\
\text { characterize the } \\
\text { sample). }\end{array}$ & $\begin{array}{l}\text { Parents } \\
\text { (child } \\
\text { aged 3- } \\
10 \text { years) } \\
=27\end{array}$ & $\begin{array}{l}\text { Country: US } \\
\text { Gender, Female: } 85.2 \% \\
\text { Age, mean (SD) } 37.6(6.5) \text { years } \\
\text { Race/ethnicity/culture/language, } \\
\text { American Indian/Alaskan Native } 3.7 \% \text {, } \\
\text { Asian 3.7\%, Black or African American } \\
29.6 \% \text {, White } 63.0 \% \\
\text { Socioeconomic status, college degree or } \\
\text { higher } 85.1 \% \text {, full-time employment: } \\
74.1 \% \text {; mean (SD) hours worked per } \\
\text { week: } 39.4(8.4) \text {, annual income } \geq \\
\$ 100,000: 53.6 \%\end{array}$ & $\begin{array}{l}\text { Pediatric } \\
\text { medical } \\
\text { center } \\
\text { (unclear } \\
\text { precisely } \\
\text { where data } \\
\text { were } \\
\text { collected). }\end{array}$ & $\begin{array}{l}\text { Study flyer emailed to } \sim 15,000 \\
\text { employees of a large pediatric } \\
\text { medical center. Of the } 72 \\
\text { individuals who responded to } \\
\text { the study flier }(\sim 5 \%), 51 \\
\text { individuals were screened, } 48 \\
\text { met eligibility criteria (two } \\
\text { unable to attend focus group } \\
\text { times, one ate dinner out }<3 \\
\text { times/week). A further } 21 \\
\text { subsequently did not attend the } \\
\text { focus groups. }\end{array}$ & $\begin{array}{l}\text { Observational, } \\
\text { cross-sectional } \\
\text { using mixed- } \\
\text { methods: } \\
\text { written } \\
\text { questionnaire, } \\
\text { anthropometric } \\
\text { measurements, } \\
\text { visual portion } \\
\text { size estimation } \\
\text { task. }\end{array}$ & $\begin{array}{l}\text { Parents' } \\
\text { estimate of a } \\
\text { child-size } \\
\text { portion }\end{array}$ & $\begin{array}{l}\text { Visual portion size estimation task: parents } \\
\text { given eight images of different portion } \\
\text { size for baked chicken }(28.35 \mathrm{~g}, 56.70 \mathrm{~g}, \\
85.05 \mathrm{~g}, 113.40 \mathrm{~g}, 141.75 \mathrm{~g}, 170.10 \mathrm{~g}, \\
226.80 \mathrm{~g}, \text { or } 340.19 \mathrm{~g}) \text { and for kernel corn } \\
(4.92 \mathrm{~mL}, 14.79 \mathrm{~mL}, 0.06 \mathrm{~L}, 0.08 \mathrm{~L}, \\
0.12 \mathrm{~L}, 0.16 \mathrm{~L}, 0.18 \mathrm{~L} \text { or } 0.24 \mathrm{~L}) \text { and asked } \\
\text { to identify which best represented a child- } \\
\text { sized portion. Parent estimates were } \\
\text { subtracted from the standard portion sizes } \\
\text { of these foods for a meal to yield a portion } \\
\text { size accuracy score. }\end{array}$ & $\begin{array}{l}\text { Not } \\
\text { reported } \\
\text { (for portion } \\
\text { size } \\
\text { estimation } \\
\text { task). }\end{array}$ \\
\hline
\end{tabular}

Plating up appropriate portion sizes for children 


\begin{tabular}{|c|c|c|c|c|c|c|c|c|c|}
\hline \multirow{2}{*}{$\begin{array}{l}\text { Lead } \\
\text { Author } \\
\text { (Year) }\end{array}$} & \multirow[t]{2}{*}{ Research aim(s) } & \multicolumn{2}{|l|}{ Subjects } & \multirow[t]{2}{*}{ Setting } & \multirow{2}{*}{$\begin{array}{l}\text { Subject selection (exclusion } \\
\text { criteria) }\end{array}$} & \multirow[t]{2}{*}{ Study design } & \multicolumn{3}{|l|}{ Outcome(s) } \\
\hline & & $\mathbf{N}$ & Characteristics & & & & Outcome & Measurement & $\begin{array}{l}\text { Validity / } \\
\text { Reliability }\end{array}$ \\
\hline & & & $\begin{array}{l}\text { Marital status, married: } 70.4 \% \\
\text { Weight status, mean (SD) BMI } 33.5 \\
(9.1) \mathrm{kg} / \mathrm{m}^{2} \text {, overweight or obese: } 81.5 \%\end{array}$ & & & & & & \\
\hline $\begin{array}{l}\text { Silvia } \\
\text { Garcia et } \\
\text { al. (2016) } \\
(32)\end{array}$ & $\begin{array}{l}\text { To examine the } \\
\text { association } \\
\text { between maternal } \\
\text { autonomy } \\
\text { promoting serving } \\
\text { practices and child } \\
\text { appetite } \\
\text { regulation. }\end{array}$ & $\begin{array}{l}\text { Mothers } \\
\text { (child } \\
\text { aged 4-5 } \\
\text { years) = } \\
186\end{array}$ & $\begin{array}{l}\text { Country, US } \\
\text { Age, mean (SD) years: } 31.5 \text { (6.5) } \\
\text { Race/ethnicity/culture/language, Origin } \\
\text { of birth: Mexico } 60.4 \% \\
\text { Socioeconomic status, high school } \\
\text { diploma or less } 64.7 \% \text {, employed } 23.5 \% \\
\text { Marital status, married } 60.0 \% \\
\text { Child gender, Female: } 47.6 \% \\
\text { Child age, mean (SD) years: } 4.34 \text { (0.48) } \\
\text { Child weight status, BMI < } 85 \text { th } \\
\text { percentile } 52.9 \%\end{array}$ & $\begin{array}{l}\text { Laboratory } \\
\text { setting. }\end{array}$ & $\begin{array}{l}\text { Parents were recruited from } \\
\text { Head Start centers (numbers } \\
\text { not reported) in a large urban } \\
\text { city in southeast United States. } \\
\text { Participating mothers were } \\
\text { participants of a larger study } \\
\text { examining child self-regulation. } \\
\text { If parents had more than one } \\
\text { child aged } 4-5 \text { years, one of } \\
\text { these children was selected at } \\
\text { random. }\end{array}$ & $\begin{array}{l}\text { Observational, } \\
\text { cross-sectional } \\
\text { using } \\
\text { quantitative } \\
\text { methods: } \\
\text { written } \\
\text { questionnaire, } \\
\text { anthropometric } \\
\text { measurements } \\
\text { and buffet meal } \\
\text { serving task. }\end{array}$ & $\begin{array}{l}\text { Maternal } \\
\text { autonomy } \\
\text { promoting } \\
\text { practices in } \\
\text { serving foods } \\
\text { and drinks. }\end{array}$ & $\begin{array}{l}\text { Buffet meal serving task: mothers were } \\
\text { instructed to help themselves and their } \\
\text { child to whatever food and beverages they } \\
\text { liked from those available. Foods included } \\
\text { penne pasta, tomato sauce, meat flavored } \\
\text { sauce, rolls, salad, salad dressing, carrots, } \\
\text { broccoli, corn, applesauce, peaches, butter, } \\
\text { parmesan cheese, pudding cups, and } \\
\text { cookies. Beverages included milk and } \\
\text { water. The meal was video-recorded and } \\
\text { later coded by two bilingual undergraduate } \\
\text { students for maternal autonomy promotion } \\
\text { practices using an observational coding } \\
\text { system developed for the study. }\end{array}$ & $\begin{array}{l}\text { Percentage } \\
\text { agreement } \\
\text { between the } \\
\text { two coders } \\
\text { of the } \\
\text { videotapes } \\
\text { ranged } \\
\text { from } 63 \% \\
\text { to } 100 \% \\
\text { with a } \\
\text { mean } 83 \% \\
\text { (based on a } \\
\text { sample of } \\
34 / 186 \\
\text { video } \\
\text { recordings). }\end{array}$ \\
\hline $\begin{array}{l}\text { Stromberg } \\
\text { et al. } \\
\text { (2016) (33) }\end{array}$ & $\begin{array}{l}\text { To examine } \\
\text { factors that may } \\
\text { influence the } \\
\text { portion sizes a } \\
\text { mother serves her } \\
\text { child at a } \\
\text { mealtime. }\end{array}$ & $\begin{array}{l}\text { Mothers } \\
\text { (child } \\
\text { aged 3-6 } \\
\text { years) = } \\
29 .\end{array}$ & $\begin{array}{l}\text { Country, US } \\
\text { Age, mean (SD) years: } 34.2(8.0) \\
\text { Socioeconomic status, family income }> \\
\$ 60,000 \text { USD: } 31.0 \%(28 / 29 \text { responded) } \\
\text { Marital status, married: } 72.4 \% \\
\text { Weight status, BMI } \geq 25 \mathrm{~kg} / \mathrm{m}^{2}: 51.7 \% \\
\text { Child gender, Female: } 51.7 \% \\
\text { Child age, mean (SD) years: } 4.03 \text { (0.94) } \\
\text { Child race/ethnicity } / \text { culture/language, } \\
\text { Caucasian: } 41.4 \% \text {, African American: } \\
37.9 \% \\
\text { Child weight status, BMI }<85 \text { th } \\
\text { percentile: } 79.3 \%\end{array}$ & $\begin{array}{l}\text { Laboratory } \\
\text { setting. }\end{array}$ & $\begin{array}{l}\text { Mothers recruited via pediatric } \\
\text { offices, preschools, day care } \\
\text { centers, and local media. } \\
\text { Twenty nine of the } 30 \text { mother- } \\
\text { child dyads that were initially } \\
\text { eligible at phone screen (i.e. } \\
\text { both mother and child were free } \\
\text { of medical conditions requiring } \\
\text { special dietary restrictions) and } \\
\text { arrived for their appointment } \\
\text { were included in the sample. } \\
\text { One mother-child dyad was } \\
\text { excluded as a result of eating } \\
\text { within } 2 \mathrm{~h} \text { prior to the session. }\end{array}$ & $\begin{array}{l}\text { Observational, } \\
\text { cross-sectional } \\
\text { using } \\
\text { quantitative } \\
\text { methods: } \\
\text { written } \\
\text { questionnaire, } \\
\text { anthropometric } \\
\text { measurements, } \\
\text { and maternal } \\
\text { food and } \\
\text { beverage } \\
\text { portioning } \\
\text { activity }\end{array}$ & $\begin{array}{l}\text { Calories } \\
\text { mother served } \\
\text { to child. }\end{array}$ & $\begin{array}{l}\text { Portioning activity: Mothers asked to } \\
\text { prepare a lunch/dinner plate for } \\
\text { themselves and their child from the foods } \\
\text { and beverages available (baby carrots, } \\
\text { cheese slices, apple slices, crackers, } \\
\text { biscuits/cookies, macaroni and cheese, } \\
\text { vegetable lasagna, chicken nuggets, water, } \\
1 \% \text { milk and apple juice). Children also } \\
\text { allowed to ask their mother to serve } \\
\text { desired food items. During the meal, } \\
\text { mother and child were observed by trained } \\
\text { coders who recorded amounts of foods } \\
\text { served and consumed using an established } \\
\text { protocol. Left overs were subtracted from } \\
\text { amounts consumed. Perception of hunger: } \\
\text { Mothers responded to two items in the } \\
\text { written questionnaire: (1) mother asked to } \\
\text { rate her own hunger at present, (2) mother } \\
\text { asked to rate her child's hunger at present. } \\
\text { Child and mother height and weight were } \\
\text { measured using a digital scale to the } \\
\text { nearest } 0.1 \mathrm{~kg} \text { and a stadiometer to the } \\
\text { nearest } 0.1 \mathrm{~cm} \text {, respectively. }\end{array}$ & $\begin{array}{l}\text { Portioning } \\
\text { activity } \\
\text { based on } \\
\text { previously } \\
\text { established } \\
\text { protocol } \\
\text { with inter- } \\
\text { observer } \\
\text { reliability } \\
\text { and } \\
\text { accuracy } \\
\text { (average } \\
\text { ICC } 0.99 \text { ). }\end{array}$ \\
\hline
\end{tabular}

Plating up appropriate portion sizes for children 


\begin{tabular}{|c|c|c|c|c|c|c|c|c|c|}
\hline \multirow{2}{*}{$\begin{array}{l}\text { Lead } \\
\text { Author } \\
\text { (Year) }\end{array}$} & \multirow[t]{2}{*}{ Research aim(s) } & \multicolumn{2}{|l|}{ Subjects } & \multirow[t]{2}{*}{ Setting } & \multirow{2}{*}{$\begin{array}{l}\text { Subject selection (exclusion } \\
\text { criteria) }\end{array}$} & \multirow[t]{2}{*}{ Study design } & \multicolumn{3}{|l|}{ Outcome(s) } \\
\hline & & $\mathbf{N}$ & Characteristics & & & & Outcome & Measurement & $\begin{array}{l}\text { Validity / } \\
\text { Reliability }\end{array}$ \\
\hline $\begin{array}{l}\text { Vittrup et } \\
\text { al. (2018) } \\
\text { (29) }\end{array}$ & $\begin{array}{l}\text { To investigate the } \\
\text { eating and } \\
\text { exercise habits of } \\
\text { families with } \\
\text { young children. }\end{array}$ & $\begin{array}{l}\text { Parents } \\
\text { and } \\
\text { caregiver } \\
\mathrm{s} \text { (child } \\
\text { aged } 3- \\
10 \text { years) } \\
=205\end{array}$ & $\begin{array}{l}\text { Country, US } \\
\text { Gender, Mothers: } 87 \% \\
\text { Age, mean (SD) years: } 32.7(8.5) \\
\text { Race/ethnicity/culture/language, } \\
\text { Hispanic: } 49 \% \text {, White: } 8 \% \text {, Black } 8 \% \text {, } \\
\text { Not reported 35\% } \\
\text { Socioeconomic status, some college or } \\
\text { higher } 57 \% \text {, annual income of }< \\
\$ 40,000: 80 \% \\
\text { Marital status, Married: } 54 \% \\
\text { Weight status, overweight or obese: } \\
69 \% \\
\text { Child gender, Female: } 53 \% \\
\text { Child age, mean (SD) years: } 4.4(1.7) \\
\text { Child weight status, overweight or } \\
\text { obese: } 40 \%\end{array}$ & $\begin{array}{l}\text { Parents } \\
\text { completed } \\
\text { questionnaire } \\
\text { either online } \\
\text { or in paper- } \\
\text { based written } \\
\text { format. }\end{array}$ & $\begin{array}{l}\text { Parents recruited via flyers } \\
\text { distributed though preschools } \\
\text { and Head Start centers located } \\
\text { in southwestern areas } \\
\text { metropolitan. }\end{array}$ & $\begin{array}{l}\text { Observational, } \\
\text { cross-sectional } \\
\text { using } \\
\text { quantitative } \\
\text { methods: online } \\
\text { or written } \\
\text { questionnaire }\end{array}$ & $\begin{array}{l}\text { Parental } \\
\text { method of } \\
\text { determination } \\
\text { of portion } \\
\text { sizes for } \\
\text { children. }\end{array}$ & $\begin{array}{l}\text { Parents were asked the question 'How do } \\
\text { you determine portion sizes for your } \\
\text { child?' as an open-response question, with } \\
\text { responses categorized quantitatively. }\end{array}$ & $\begin{array}{l}\text { Some } \\
\text { questions } \\
\text { based on } \\
\text { previous } \\
\text { survey on } \\
\text { childhood } \\
\text { obesity } \\
\text { (unclear } \\
\text { which). }\end{array}$ \\
\hline
\end{tabular}

Abbreviations: BMI, Body Mass Index; CDC, Centers for Disease Control and prevention; SD, Standard Deviation; UK, United Kingdom; US, United States. 


\begin{tabular}{|c|c|c|c|c|c|c|c|c|}
\hline \multirow{2}{*}{$\begin{array}{l}\text { Lead } \\
\text { Author } \\
\text { (Year) }\end{array}$} & \multirow[b]{2}{*}{ Research aim(s) } & \multicolumn{2}{|l|}{ Subjects } & \multirow[t]{2}{*}{ Setting } & \multirow[t]{2}{*}{ Subject selection } & \multirow[t]{2}{*}{ Study design } & \multirow{2}{*}{$\begin{array}{l}\text { Researcher } \\
\text { characteristics }\end{array}$} & \multirow[t]{2}{*}{ Data analysis } \\
\hline & & $\mathbf{N}$ & Characteristics & & & & & \\
\hline $\begin{array}{l}\text { Berge et al. } \\
\text { (2016) (44) }\end{array}$ & $\begin{array}{l}\text { To describe parent } \\
\text { feeding practices } \\
\text { with siblings. }\end{array}$ & $\begin{array}{l}\text { Parents } \\
\text { (child } \\
\text { aged } 2- \\
12 \text { years) } \\
=88\end{array}$ & $\begin{array}{l}\text { Country, US } \\
\text { Gender, Female: } 94 \% \\
\text { Age, mean (SD) years: } 34 \text { (7) } \\
\text { Race/ethnicity/culture/language, African } \\
\text { American: } 64 \% \\
\text { Socioeconomic status, employed: } 49 \% \text {, annual } \\
\text { household income }<\$ 35,000: 77 \% \\
\text { Weight status, overweight or obese: } 82 \% \\
\text { Child weight status, } \geq 85 \text { percentile: target child } \\
52 \% \text {, sibling } 42 \% \\
\text { Child age, mean (SD) years: target child } 9(2) \text {, } \\
\text { sibling } 9(4) \\
\text { Child gender, Female: target child } 47 \% \text {, sibling } \\
56 \%\end{array}$ & $\begin{array}{l}\text { Parents were } \\
\text { interviewed } \\
\text { in their homes } \\
\text { in } \\
\text { Minneapolis } \\
\text { or St Paul, } \\
\text { Minnesota }\end{array}$ & $\begin{array}{l}\text { Parents were sourced from a larger } \\
\text { study ( } \mathrm{n}=120 \text { ) examining parents' } \\
\text { feeding practices with two child siblings } \\
\text { in the same household. Eligible, } \\
\text { consenting parents }(\mathrm{n}=88) \text { had at least } \\
\text { one child sibling aged } 2-18 \text { years who } \\
\text { lived with the sibling and had the same } \\
\text { parent/primary caregiver. }\end{array}$ & $\begin{array}{l}\text { Observational, } \\
\text { cross-sectional } \\
\text { using } \\
\text { qualitative } \\
\text { methods: Face- } \\
\text { to-face } \\
\text { interviews }\end{array}$ & $\begin{array}{l}\text { Interviewers were } \\
\text { research staff of } \\
\text { comparable } \\
\text { ethnicities as the } \\
\text { study sample, } \\
\text { trained using } \\
\text { standardized } \\
\text { protocols, and } \\
\text { required to reach } \\
\text { certification level } \\
\text { in qualitative } \\
\text { interviewing } \\
\text { skills. }\end{array}$ & $\begin{array}{l}\text { Data were coded using hybrid } \\
\text { deductive and inductive content } \\
\text { analysis approach. Coding was } \\
\text { conducted by two authors with } \\
95 \% \text { inter-coder agreement on the } \\
\text { first } 20 \text { interview transcripts. Codes } \\
\text { were reduced to main themes. } \\
\text { Themes present in at least one-third } \\
\text { of interviews being retained. }\end{array}$ \\
\hline $\begin{array}{l}\text { Blake et al. } \\
\text { (2015) (45) }\end{array}$ & $\begin{array}{l}\text { To examine } \\
\text { parents' } \\
\text { conceptualizations } \\
\text { of portion size and } \\
\text { the strategies they } \\
\text { use to portion } \\
\text { snacks in the } \\
\text { context of pre- } \\
\text { school aged } \\
\text { children's } \\
\text { snacking. }\end{array}$ & $\begin{array}{l}\text { Parents } \\
\text { (child } \\
\text { aged 3-5 } \\
\text { years) }= \\
60\end{array}$ & $\begin{array}{l}\text { Country, US } \\
\text { Gender, Female: } 93 \% \\
\text { Race/ethnicity/culture/language, White: } 28 \% \text {, } \\
\text { African American: } 38 \% \text {, Hispanic: } 33 \% \\
\text { Socioeconomic status, some college or higher: } \\
53 \% \text {, employed } 41 \% \text {, WIC participation } 70 \% \text {, } \\
\text { Food Stamps/SNAP/EBT participation: } 80 \% \text {, } \\
\text { free/reduced school meals: } 47 \% \text {, Head Start } \\
\text { program: } 35 \% \text {, experienced food insecurity in } \\
\text { prior } 12 \text { months: } 43 \% \\
\text { Marital status, married/living with partner: } 38 \% \\
\text { Weight status, overweight or obese: } 53 \%\end{array}$ & $\begin{array}{l}\text { Specific } \\
\text { interview site } \\
\text { not disclosed, } \\
\text { although } \\
\text { parents } \\
\text { resided in } \\
\text { Philadelphia } \\
\text { and Boston. }\end{array}$ & $\begin{array}{l}\text { Participants were recruited using flyers } \\
\text { posted in WIC offices and online } \\
\text { community listings such as Craigslist. } \\
\text { Inclusion criteria were parents aged } 18 \\
\text { years or older primarily responsible for } \\
\text { feeding child, low-income household, } \\
\text { and child free of severe food } \\
\text { allergy(ies), chronic medical condition } \\
\text { or developmental disorder that } \\
\text { influenced feeding. }\end{array}$ & $\begin{array}{l}\text { Observational, } \\
\text { cross-sectional } \\
\text { using } \\
\text { qualitative } \\
\text { methods: Semi- } \\
\text { structured } \\
\text { interviews }\end{array}$ & $\begin{array}{l}\text { Five research } \\
\text { assistants } \\
\text { including one } \\
\text { bilingual assistant } \\
\text { (English-Spanish) } \\
\text { conducted the } \\
\text { interviews. An } \\
\text { expert in } \\
\text { qualitative } \\
\text { methods trained } \\
\text { the interviewers to } \\
\text { conduct the } \\
\text { qualitative in- } \\
\text { depth interviews } \\
\text { during a two-day } \\
\text { workshop. }\end{array}$ & $\begin{array}{l}\text { Interview transcripts were coded } \\
\text { for the theme 'portion size' by one } \\
\text { research assistant and sub-themes } \\
\text { identified and defined through peer } \\
\text { discussion. Portion size sub-themes } \\
\text { were then compared across parental } \\
\text { race/ ethnicity, education, and } \\
\text { household food security using } \\
\text { coding matrices. }\end{array}$ \\
\hline $\begin{array}{l}\text { Croker et } \\
\text { al. (2009) } \\
\text { (38) }\end{array}$ & $\begin{array}{l}\text { To investigate } \\
\text { parents' attitudes, } \\
\text { knowledge, } \\
\text { practices and } \\
\text { concerns about } \\
\text { appropriate } \\
\text { portions for } \\
\text { children. }\end{array}$ & $\begin{array}{l}\begin{array}{l}\text { Mothers } \\
\text { (child }\end{array} \\
\text { aged } 8- \\
11 \text { years) } \\
=14\end{array}$ & $\begin{array}{l}\text { Country, England } \\
\text { Race/ethnicity/culture/language: white British: } \\
86 \% \text {, black British: } 7 \% \text {, Asian: } 7 \% \\
\text { Socioeconomic status, bachelor degree or higher: } \\
36 \% \\
\text { Child gender, Female: } 64 \%\end{array}$ & $\begin{array}{l}\text { Parents of } \\
\text { children in } \\
\text { participating } \\
\text { schools in } \\
\text { London, } \\
\text { England. } \\
\text { Specific site } \\
\text { of focus } \\
\text { groups not } \\
\text { disclosed. }\end{array}$ & $\begin{array}{l}\text { Parents }(\mathrm{N}=398 / 786) \text { recruited via } \\
\text { schools agreed to take part in a prior } \\
\text { study on the impact of feedback to } \\
\text { parents on their child's weight. Of those } \\
\text { volunteering for further research ( } \mathrm{n}= \\
160), 30 \text { were randomly selected and } \\
\text { invited to participate in focus groups for } \\
\text { this research, of which } 14 \text { agreed. }\end{array}$ & $\begin{array}{l}\text { Observational, } \\
\text { cross-sectional } \\
\text { using mixed- } \\
\text { methods: } \\
\text { quantitative } \\
\text { weighing task } \\
\text { and qualitative } \\
\text { focus groups }\end{array}$ & $\begin{array}{l}\text { Each focus group } \\
\text { was conducted by } \\
\text { the same two } \\
\text { trained } \\
\text { researchers. } \\
\text { Details of their } \\
\text { characteristics not } \\
\text { provided. }\end{array}$ & $\begin{array}{l}\text { Transcripts of each focus group } \\
\text { were read by several members of } \\
\text { the research group and key issues } \\
\text { identified and tabulated with } \\
\text { supporting quotes. Key themes } \\
\text { were those discussed most often } \\
\text { and at greatest length by three or } \\
\text { more focus groups. }\end{array}$ \\
\hline
\end{tabular}

Plating up appropriate portion sizes for children 


\begin{tabular}{|c|c|c|c|c|c|c|c|c|}
\hline \multirow{2}{*}{$\begin{array}{l}\text { Lead } \\
\text { Author } \\
\text { (Year) }\end{array}$} & \multirow[b]{2}{*}{ Research aim(s) } & \multicolumn{2}{|l|}{ Subjects } & \multirow[t]{2}{*}{ Setting } & \multirow[t]{2}{*}{ Subject selection } & \multirow[t]{2}{*}{ Study design } & \multirow{2}{*}{$\begin{array}{l}\text { Researcher } \\
\text { characteristics }\end{array}$} & \multirow[t]{2}{*}{ Data analysis } \\
\hline & & $\mathbf{N}$ & Characteristics & & & & & \\
\hline $\begin{array}{l}\text { Curtis et } \\
\text { al. (2017) } \\
\text { (39) }\end{array}$ & $\begin{array}{l}\text { To explore } \\
\text { parents' } \\
\text { capability, } \\
\text { opportunity, and } \\
\text { motivation } \\
\text { towards portion } \\
\text { control behaviors } \\
\text { with their } \\
\text { children. }\end{array}$ & $\begin{array}{l}\begin{array}{l}\text { Parents } \\
\text { (child }\end{array} \\
\text { aged 5- } \\
11 \text { years) } \\
=22\end{array}$ & $\begin{array}{l}\text { Country, England } \\
\text { Gender, Female: } 82 \% \\
\text { Child weight status, (parents recruited from } \\
\text { childhood weight management programs) } \\
\text { overweight (6/15), 'very overweight' (8/15). }\end{array}$ & $\begin{array}{l}\text { Parent focus } \\
\text { groups } \\
\text { conducted at } \\
\text { the university } \\
\text { and } \\
\text { community } \\
\text { settings. }\end{array}$ & $\begin{array}{l}\text { Parents of overweight children were } \\
\text { recruited from the local public health } \\
\text { department and community family } \\
\text { weight management groups }(15 / 22) \text {, and } \\
\text { parents of healthy weight children from } \\
\text { the researchers' university }(7 / 22) \text {. } \\
\text { Eligible parents ( } \mathrm{n}=43 \text { ) had at least one } \\
\text { child aged } \geq 5 \text { years and owned a } \\
\text { mobile phone. Of these, } 22 \text { parents } \\
\text { agreed to participate. }\end{array}$ & $\begin{array}{l}\text { Observational, } \\
\text { cross-sectional } \\
\text { using } \\
\text { qualitative } \\
\text { methods: } \\
\text { qualitative } \\
\text { focus groups }\end{array}$ & $\begin{array}{l}\text { Details of their } \\
\text { characteristics not } \\
\text { provided. }\end{array}$ & $\begin{array}{l}\text { Transcripts were analyzed by two } \\
\text { researchers independently. Text } \\
\text { was coded for basic interpretation } \\
\text { and then mapped against the } \\
\text { capability opportunity motivation } \\
\text { behavior model and a theoretical } \\
\text { domains framework based on key } \\
\text { theoretical constructs relevant for } \\
\text { behavior change. }\end{array}$ \\
\hline $\begin{array}{l}\text { Douglas et } \\
\text { al. (2014) } \\
\text { (40) }\end{array}$ & $\begin{array}{l}\text { To explore } \\
\text { mothers' } \\
\text { perspectives about } \\
\text { the nature and } \\
\text { causes of } \\
\text { childhood obesity, } \\
\text { their views and } \\
\text { experiences of } \\
\text { managing their } \\
\text { child's weight, } \\
\text { and about } \\
\text { effective weight } \\
\text { management } \\
\text { strategies. }\end{array}$ & $\begin{array}{l}\text { Mothers } \\
\text { (child } \\
\text { aged 3-4 } \\
\text { years) }= \\
34\end{array}$ & $\begin{array}{l}\text { Country, Scotland } \\
\text { Age, years range } 23-42 \text { (median } 37 \text { ) } \\
\text { Socioeconomic status, various occupations } \\
\text { (manual, professional, self-employed and full- } \\
\text { time carer) } \\
\text { Child weight status, } 2 / 34 \text { mother believed their } \\
\text { child had a weight problem }\end{array}$ & $\begin{array}{l}\text { Focus groups } \\
\text { conducted in } \\
\text { eight various } \\
\text { community- } \\
\text { based } \\
\text { locations } \\
\text { throughout } \\
\text { North-East } \\
\text { Scotland. }\end{array}$ & $\begin{array}{l}\text { Parents and carers from } 36 \text { pre-school } \\
\text { nurseries in North-East Scotland were } \\
\text { sent invitation letters, of which } 34 \\
\text { agreed to participate. }\end{array}$ & $\begin{array}{l}\text { Observational, } \\
\text { cross-sectional } \\
\text { using } \\
\text { qualitative } \\
\text { methods: } \\
\text { qualitative } \\
\text { focus groups }\end{array}$ & $\begin{array}{l}\text { Details of their } \\
\text { characteristics not } \\
\text { provided. }\end{array}$ & $\begin{array}{l}\text { Interview transcripts were read and } \\
\text { re-read independently by two } \\
\text { researchers to draft and then } \\
\text { negotiate a coding framework. } \\
\text { Throughout coding new themes } \\
\text { were integrated by constant } \\
\text { comparison to the framework, and } \\
\text { disconfirming, dominant or } \\
\text { marginalized data considered. }\end{array}$ \\
\hline $\begin{array}{l}\text { Flores et } \\
\text { al. (2012) } \\
\text { (41) }\end{array}$ & $\begin{array}{l}\text { To identify } \\
\text { parents' } \\
\text { perspectives on } \\
\text { healthy eating, } \\
\text { physical activity, } \\
\text { and weight- } \\
\text { management } \\
\text { strategies for } \\
\text { overweight Latino } \\
\text { children. }\end{array}$ & $\begin{array}{l}\text { Parents } \\
\text { (child } \\
\text { aged 6- } \\
17 \text { years; } \\
\text { median } \\
9)=19\end{array}$ & $\begin{array}{l}\text { Country, US } \\
\text { Age, years range } 26-61 \text { (median } 35 \text { ) } \\
\text { Race/ethnicity/culture/language, undocumented } \\
\text { immigrant: } 26 \% \\
\text { Socioeconomic status, graduated high school: } \\
79 \% \text {, annual family income } \leq \$ 25,000: 42 \% \\
\text { Marital status, married and living with spouse: } \\
84 \% \\
\text { Child age, years range 6-17 (median 9) } \\
\text { Child weight status, } \geq 85 \text { percentile } 40 \%, \geq 95 \\
\text { percentile } 60 \%\end{array}$ & $\begin{array}{l}\text { Milwaukee, } \\
\text { Wisconsin. } \\
\text { Specific site } \\
\text { of focus } \\
\text { groups not } \\
\text { disclosed. }\end{array}$ & $\begin{array}{l}\text { Ten parents invited to each of the four } \\
\text { focus groups, of which } 19 \text { participated: } \\
\text { Mexican- } \\
\text { American }(n=4) \text {; Mexican-American } \\
\text { immigrant }(n=8) \text {; Puerto Rican }(n=3) \text {; } \\
\text { other Latino }(n=4) \text {. }\end{array}$ & $\begin{array}{l}\text { Observational, } \\
\text { cross-sectional } \\
\text { using } \\
\text { qualitative } \\
\text { methods: } \\
\text { qualitative } \\
\text { focus groups }\end{array}$ & $\begin{array}{l}\text { Details of their } \\
\text { characteristics not } \\
\text { provided. }\end{array}$ & $\begin{array}{l}\text { Transcripts were coded } \\
\text { thematically, independently by } \\
\text { reviewers and differences resolved } \\
\text { by consensus. Common themes } \\
\text { across groups were then identified } \\
\text { by three observers to create a } \\
\text { taxonomy of themes highlighting } \\
\text { similarities and differences across } \\
\text { groups and specific study domains } \\
\text { of: healthy eating, physical activity, } \\
\text { and weight-management strategies. }\end{array}$ \\
\hline $\begin{array}{l}\text { Herman et } \\
\text { al. (2012) } \\
\text { (18) }\end{array}$ & $\begin{array}{l}\text { To understand the } \\
\text { contextual factors } \\
\text { that might } \\
\text { influence how }\end{array}$ & $\begin{array}{l}\text { Mothers } \\
\text { (child } \\
\text { aged 36- } \\
66\end{array}$ & $\begin{array}{l}\text { Country, US } \\
\text { Age, mean years } 27.5 \text { (range 20-41) } \\
\text { Race/ethnicity/culture/language, Black: 91\% }\end{array}$ & $\begin{array}{l}\text { Focus groups } \\
\text { conducted at } \\
\text { Temple } \\
\text { University, }\end{array}$ & $\begin{array}{l}\text { Mothers were recruited from the Special } \\
\text { SNAP for WIC in low-income areas of } \\
\text { Philadelphia, Pennsylvania. Of the } 88 \\
\text { mothers interested, } 70 \text { met study }\end{array}$ & $\begin{array}{l}\text { Observational, } \\
\text { cross-sectional } \\
\text { using } \\
\text { qualitative }\end{array}$ & $\begin{array}{l}\text { Lead researcher of } \\
\text { focus groups had } \\
\text { background in } \\
\text { sociology and }\end{array}$ & $\begin{array}{l}\text { Transcriptions were analyzed } \\
\text { inductively using the constant } \\
\text { comparison method. Three } \\
\text { researchers independently read the }\end{array}$ \\
\hline
\end{tabular}

Plating up appropriate portion sizes for children 


\begin{tabular}{|c|c|c|c|c|c|c|c|c|}
\hline \multirow{2}{*}{$\begin{array}{l}\text { Lead } \\
\text { Author } \\
\text { (Year) }\end{array}$} & \multirow[b]{2}{*}{ Research aim(s) } & \multicolumn{2}{|l|}{ Subjects } & \multirow[t]{2}{*}{ Setting } & \multirow[t]{2}{*}{ Subject selection } & \multirow[t]{2}{*}{ Study design } & \multirow{2}{*}{$\begin{array}{l}\text { Researcher } \\
\text { characteristics }\end{array}$} & \multirow[t]{2}{*}{ Data analysis } \\
\hline & & $\mathbf{N}$ & Characteristics & & & & & \\
\hline & $\begin{array}{l}\text { low-income } \\
\text { mothers felt about } \\
\text { limiting children's } \\
\text { portion sizes and } \\
\text { their intake of } \\
\text { foods high in solid } \\
\text { fats and/or added } \\
\text { sugars and } \\
\text { mothers' } \\
\text { aspirations in } \\
\text { feeding their } \\
\text { children. }\end{array}$ & $\begin{array}{l}\text { months) } \\
=32\end{array}$ & $\begin{array}{l}\text { Socioeconomic status, graduated high school or } \\
\text { less: } 47 \% \text {, food insecure: } 22 \% \text {, } \\
\text { Marital status, married: } 19 \% \text {, lives with partner } \\
\text { or husband: } 53 \% \\
\text { Weight status, overweight or obese: } 71 \% \\
\text { Child age, mean months } 50.9 \text { (range } 36.9-65.9 \text { ) } \\
\text { Child gender, Female: } 47 \%\end{array}$ & $\begin{array}{l}\text { Philadelphia, } \\
\text { Pennsylvania. }\end{array}$ & $\begin{array}{l}\text { eligibility criteria, of which } 38 \text { attended } \\
\text { one of eight scheduled focus groups. }\end{array}$ & $\begin{array}{l}\text { methods: } \\
\text { qualitative } \\
\text { focus groups }\end{array}$ & $\begin{array}{l}\text { child } \\
\text { development. } \\
\text { Data analyses } \\
\text { were led by a } \\
\text { senior investigator } \\
\text { with a background } \\
\text { in Public Health } \\
\text { and over } 15 \text { years } \\
\text { of experience } \\
\text { conducting } \\
\text { qualitative } \\
\text { research with low- } \\
\text { income mothers. }\end{array}$ & $\begin{array}{l}\text { transcripts, identified a set of } \\
\text { themes with supporting text, and } \\
\text { then condensed these themes by } \\
\text { discussion. }\end{array}$ \\
\hline $\begin{array}{l}\text { Jacquier et } \\
\text { al. (2017) } \\
\text { (48) }\end{array}$ & $\begin{array}{l}\text { To examine } \\
\text { caregiver attitudes } \\
\text { and perceptions } \\
\text { towards provision } \\
\text { of foods and } \\
\text { beverages in- } \\
\text { between meals } \\
\text { and what } \\
\text { constitutes a snack } \\
\text { or snacking } \\
\text { occasion. }\end{array}$ & $\begin{array}{l}\text { Caregiver } \\
\text { s (child } \\
\text { aged } 1- \\
5 \text { years) } \\
=19(18 \\
\text { parents, } 1 \\
\text { child- } \\
\text { minder) }\end{array}$ & $\begin{array}{l}\text { Country, Switzerland } \\
\text { Gender, Mother: } 79 \% \\
\text { Age, mean years: } 36 \\
\text { Race/ethnicity/culture/language, born in } \\
\text { Switzerland: } 68 \% \\
\text { Socio-economic status, employed } 89 \% \text {, middle- } \\
\text { high income: } 63 \% \text {, finished college: } 68 \% \\
\text { Marital status, married: } 63 \%\end{array}$ & $\begin{array}{l}\text { Face-to-face } \\
\text { interviews } \\
\text { conducted in } \\
\text { caregivers' } \\
\text { homes. }\end{array}$ & $\begin{array}{l}\text { Caregivers recruited from a database of } \\
\text { national landline telephone numbers } \\
\text { (screened over the phone). Eligible } \\
\text { caregivers were primarily responsible } \\
\text { for feeding their child aged } 1-5 \text { years, } \\
\text { were aged } 18 \text { years or older, were not } \\
\text { employed in nutrition or had recently } \\
\text { taken part in a child-feeding study and } \\
\text { resided in the French speaking region of } \\
\text { Switzerland. }\end{array}$ & $\begin{array}{l}\text { Observational, } \\
\text { cross-sectional } \\
\text { using } \\
\text { qualitative } \\
\text { methods: in- } \\
\text { depth } \\
\text { interviews }\end{array}$ & $\begin{array}{l}\text { Details of their } \\
\text { characteristics not } \\
\text { provided. }\end{array}$ & $\begin{array}{l}\text { Interview transcripts were analyzed } \\
\text { by inductive thematic analysis } \\
\text { using AtlasTi software. Initial open } \\
\text { coding of text was cross-checked } \\
\text { against the "Food Choice Process } \\
\text { Model" theoretical framework for } \\
\text { similarities/differences. Coding as } \\
\text { led by one author with two co-- } \\
\text { authors overseeing each phase of } \\
\text { the analysis. }\end{array}$ \\
\hline $\begin{array}{l}\text { Johnson et } \\
\text { al. (2015) } \\
\text { (46) }\end{array}$ & $\begin{array}{l}\text { To identify the } \\
\text { underlying } \\
\text { influences on } \\
\text { mothers' } \\
\text { behaviors when } \\
\text { preparing a plate } \\
\text { for their child, } \\
\text { how their } \\
\text { motivations and } \\
\text { goals for child } \\
\text { consumption } \\
\text { related to the } \\
\text { amounts they } \\
\text { served, and their } \\
\text { conceptions of } \\
\text { how much is } \\
\text { appropriate to } \\
\text { serve their child. }\end{array}$ & $\begin{array}{l}\text { Mothers } \\
\text { (child } \\
\text { aged } 2-5 \\
\text { years) }= \\
30 \\
\text { (included } \\
2 \\
\text { grandmot } \\
\text { hers) }\end{array}$ & $\begin{array}{l}\text { Country, US } \\
\text { Age, mean (SD) years: African American } 34 \\
\text { (9.8), Latina } 32 \text { (8.7) } \\
\text { Race/ethnicity/culture/language, African } \\
\text { American } 50 \% \text {, Latina } 50 \% \\
\text { Socioeconomic status, high school or less / GED: } \\
\text { African American } 46 \% \text {, Latina } 40 \% \text {, annual } \\
\text { income } \leq \$ 40,000 \text { : African American } 93 \% \text {, } \\
\text { Latina } 93 \% \\
\text { Weight status, overweight or obese: African } \\
\text { American } 47 \% \text {, Latina } 13 \% \\
\text { Child gender, Female: African American } 53 \% \text {, } \\
\text { Latina 33\% } \\
\text { Child age, months mean (SD): African American } \\
57.6(8.3) \text { Latina } 52.8(10.1) \\
\text { Child weight status, } \geq 85 \text { percentile: African } \\
\text { American }(\mathrm{n}=1) \text {, Latina (n = 4) }\end{array}$ & $\begin{array}{l}\text { Interviews } \\
\text { were } \\
\text { conducted at } \\
\text { the Children's } \\
\text { Eating } \\
\text { Laboratory at } \\
\text { the University } \\
\text { of Colorado, } \\
\text { Anschutz } \\
\text { Medical } \\
\text { Campus. }\end{array}$ & $\begin{array}{l}\text { Mothers were recruited via Head Start } \\
\text { centers in Denver/Aurora, Colorado via } \\
\text { flyers placed in center lobbies, referral } \\
\text { by center teachers, and direct approach } \\
\text { by research staff during morning and } \\
\text { afternoon drop-off and pick-up times at } \\
\text { the centers. }\end{array}$ & $\begin{array}{l}\text { Observational, } \\
\text { cross-sectional } \\
\text { using } \\
\text { qualitative } \\
\text { methods: } \\
\text { qualitative } \\
\text { semi-structured } \\
\text { interviews }\end{array}$ & $\begin{array}{l}\text { Researchers were } \\
\text { experienced } \\
\text { in qualitative } \\
\text { research with } \\
\text { backgrounds in } \\
\text { nutrition, child } \\
\text { development and } \\
\text { parenting related } \\
\text { to child feeding, } \\
\text { and in social } \\
\text { psychology as it } \\
\text { relates to } \\
\text { parenting and } \\
\text { childhood obesity } \\
\text { development in } \\
\text { low income } \\
\text { families. }\end{array}$ & $\begin{array}{l}\text { Interview transcripts were analyzed } \\
\text { using grounded theory. A } \\
\text { qualitative expert and the } \\
\text { interviewer created an initial code } \\
\text { manual using a constant } \\
\text { comparative method. Two coders } \\
\text { then used the coding manual to } \\
\text { independently code each transcript, } \\
\text { one or two at a time, and met } \\
\text { together to compare coding. Each } \\
\text { coded transcript was then imported } \\
\text { into NVivo software to examine } \\
\text { codes for patterns and relationships } \\
\text { among to identify higher order } \\
\text { themes that were then discussed for } \\
\text { meaning to form final conclusions } \\
\text { regarding the themes. }\end{array}$ \\
\hline
\end{tabular}

Plating up appropriate portion sizes for children 


\begin{tabular}{|c|c|c|c|c|c|c|c|c|}
\hline \multirow{2}{*}{$\begin{array}{l}\text { Lead } \\
\text { Author } \\
\text { (Year) }\end{array}$} & \multirow[b]{2}{*}{ Research aim(s) } & \multicolumn{2}{|l|}{ Subjects } & \multirow[t]{2}{*}{ Setting } & \multirow[t]{2}{*}{ Subject selection } & \multirow[t]{2}{*}{ Study design } & \multirow{2}{*}{$\begin{array}{l}\text { Researcher } \\
\text { characteristics }\end{array}$} & \multirow[t]{2}{*}{ Data analysis } \\
\hline & & $\mathbf{N}$ & Characteristics & & & & & \\
\hline $\begin{array}{l}\text { Lora et al. } \\
(2017)(42)\end{array}$ & $\begin{array}{l}\text { To examine the } \\
\text { views of Hispanic } \\
\text { mothers regarding } \\
\text { fathers' roles in } \\
\text { promoting healthy } \\
\text { behaviors at } \\
\text { home. }\end{array}$ & $\begin{array}{l}\text { Mothers } \\
\text { (child } \\
\text { aged 2-5 } \\
\text { years) }= \\
55\end{array}$ & $\begin{array}{l}\text { Country, US } \\
\text { Age, mean (SD) years: } 34.6(8.0) \\
\text { Race/ethnicity/culture/language, place of birth } \\
\text { Mexico: } 85 \% \text {, Central or South America: } 11 \% \text {, } \\
\text { United States: } 4 \% \text {, speaks only Spanish or } \\
\text { Spanish better than English: } 89 \% \\
\text { Socioeconomic status, high school education or } \\
\text { less: } 82 \% \text {, unemployed: } 78 \% \text {, SNAP participant: } \\
53 \%\end{array}$ & $\begin{array}{l}\text { Focus groups } \\
\text { conducted at } \\
\text { the local } \\
\text { Latino } \\
\text { Community } \\
\text { Development } \\
\text { Agency in } \\
\text { Oklahoma } \\
\text { City. }\end{array}$ & $\begin{array}{l}\text { Participants were recruited from } \\
\text { churches, community agencies, } \\
\text { preschools and day care centers, with } \\
\text { the assistance of a community health } \\
\text { worker, in southwest Oklahoma City. } \\
\text { Eligible mothers identified as Hispanic, } \\
\text { lived with target child and child's father, } \\
\text { and were a low-income family. }\end{array}$ & $\begin{array}{l}\text { Observational, } \\
\text { cross-sectional } \\
\text { using } \\
\text { qualitative } \\
\text { methods: } \\
\text { qualitative } \\
\text { focus groups }\end{array}$ & $\begin{array}{l}\text { Details of their } \\
\text { characteristics not } \\
\text { provided, } \\
\text { although principle } \\
\text { investigator had } \\
\text { prior experience } \\
\text { with Hispanic } \\
\text { families from } \\
\text { different countries } \\
\text { in community- } \\
\text { based programs. }\end{array}$ & $\begin{array}{l}\text { Spanish transcriptions of the focus } \\
\text { groups were translated into } \\
\text { English, and coded and analyzed } \\
\text { for themes by two researchers. } \\
\text { Analyses were informed by } \\
\text { grounded theory. }\end{array}$ \\
\hline $\begin{array}{l}\text { Martin- } \\
\text { Biggers et } \\
\text { al. (2015) } \\
(19)\end{array}$ & $\begin{array}{l}\text { To examine } \\
\text { preschool parents' } \\
\text { cognitions, } \\
\text { barriers, supports } \\
\text { and modelling of } \\
\text { key obesogenic } \\
\text { behaviors } \\
\text { (including portion } \\
\text { sizes). }\end{array}$ & $\begin{array}{l}\text { Parents } \\
\text { (child } \\
\text { aged 2-5 } \\
\text { years) }= \\
139\end{array}$ & $\begin{array}{l}\text { Country, US } \\
\text { Age, mean (SD) years: } 32.18 \text { ( } 7.12) \\
\text { Race/ethnicity/culture/language, first language: } \\
\text { Spanish: } 40 \% \\
\text { Socioeconomic status, high school or less: } 34 \% \text {, } \\
\text { food insecurity in the last year: } 27 \%\end{array}$ & $\begin{array}{l}\text { New Jersey } \\
\text { and Arizona } \\
\text { chosen due to } \\
\text { higher } \\
\text { preschool } \\
\text { childhood } \\
\text { obesity rates } \\
\text { at the time of } \\
\text { study. } \\
\text { Specific site } \\
\text { of focus } \\
\text { groups not } \\
\text { disclosed. }\end{array}$ & $\begin{array}{l}\text { Participants whose primary language } \\
\text { was English or Spanish were recruited } \\
\text { via flyers posted at community sites and } \\
\text { emails sent from workplace directories } \\
\text { in New Jersey and Arizona. }\end{array}$ & $\begin{array}{l}\text { Observational, } \\
\text { cross-sectional } \\
\text { using } \\
\text { qualitative } \\
\text { methods: } \\
\text { qualitative } \\
\text { focus groups }\end{array}$ & $\begin{array}{l}\text { Details of their } \\
\text { characteristics not } \\
\text { provided, } \\
\text { although } \\
\text { researchers were } \\
\text { fluent in the } \\
\text { language used to } \\
\text { conduct the focus } \\
\text { groups (i.e. } \\
\text { English or } \\
\text { Spanish) }\end{array}$ & $\begin{array}{l}\text { Translated transcripts were } \\
\text { analyzed using standard content } \\
\text { analysis procedures. Three trained } \\
\text { researchers identified themes } \\
\text { independently, and then compared } \\
\text { these to reach agreement. }\end{array}$ \\
\hline $\begin{array}{l}\text { Roth- } \\
\text { Yousey et } \\
\text { al. }(2012) \\
(43)\end{array}$ & $\begin{array}{l}\text { To understand } \\
\text { parent beverage } \\
\text { expectations for } \\
\text { early adolescents } \\
\text { by eating occasion } \\
\text { at home and in } \\
\text { various settings. }\end{array}$ & $\begin{array}{l}\text { Parents } \\
\text { (child } \\
\text { aged } 10- \\
13 \text { years) } \\
=49\end{array}$ & $\begin{array}{l}\text { Country, US } \\
\text { Gender, Female: } 86 \% \\
\text { Age, } 18-40 \text { years: } 59 \% \text { (range } 18-51+\text { ) } \\
\text { Race/ethnicity/culture/language, White: } 49 \% \text {, } \\
\text { Hispanic or Latino: } 33 \% \\
\text { Socioeconomic status, high school/GED or less: } \\
33 \% \text {, employed: } 55 \% \text {, participant of food } \\
\text { assistance program: } 53 \%\end{array}$ & $\begin{array}{l}\text { Specific site } \\
\text { of focus } \\
\text { groups not } \\
\text { disclosed. }\end{array}$ & $\begin{array}{l}\text { Participants who were a parent or } \\
\text { caregiver of a child aged } 10-13 \text { years, } \\
\text { were recruited using fliers posted in } \\
\text { middle schools and community centers } \\
\text { in low-income neighborhoods within a } \\
\text { large Midwestern metropolitan area. }\end{array}$ & $\begin{array}{l}\text { Observational, } \\
\text { cross-sectional } \\
\text { using } \\
\text { qualitative } \\
\text { methods: } \\
\text { qualitative } \\
\text { focus groups }\end{array}$ & $\begin{array}{l}\text { Details of their } \\
\text { characteristics not } \\
\text { provided, } \\
\text { although those } \\
\text { conducting focus } \\
\text { groups were } \\
\text { bilingual (as } \\
\text { groups were } \\
\text { conducted in } \\
\text { English and } \\
\text { Spanish) }\end{array}$ & $\begin{array}{l}\text { One transcript was coded by the } \\
\text { lead researcher. These codes were } \\
\text { then reviewed by a second } \\
\text { researcher and discussed. The } \\
\text { remaining transcripts were then } \\
\text { independently coded by the } \\
\text { researchers attaining } 83 \%-92 \% \\
\text { inter-coder reliability based on } \\
\text { every tenth statement. The two } \\
\text { researchers independently } \\
\text { identified themes using a constant } \\
\text { comparison method and differences } \\
\text { reconciled. }\end{array}$ \\
\hline
\end{tabular}

Plating up appropriate portion sizes for children 


\begin{tabular}{|c|c|c|c|c|c|c|c|c|}
\hline \multirow{2}{*}{$\begin{array}{l}\text { Lead } \\
\text { Author } \\
\text { (Year) }\end{array}$} & \multirow[b]{2}{*}{ Research aim(s) } & \multicolumn{2}{|l|}{ Subjects } & \multirow[t]{2}{*}{ Setting } & \multirow[t]{2}{*}{ Subject selection } & \multirow[t]{2}{*}{ Study design } & \multirow{2}{*}{$\begin{array}{l}\text { Researcher } \\
\text { characteristics }\end{array}$} & \multirow[t]{2}{*}{ Data analysis } \\
\hline & & $\mathbf{N}$ & Characteristics & & & & & \\
\hline $\begin{array}{l}\text { Sherry et } \\
\text { al. (2004) } \\
\text { (20) }\end{array}$ & $\begin{array}{l}\text { To explore } \\
\text { maternal attitudes, } \\
\text { concerns, and } \\
\text { practices related } \\
\text { to child feeding } \\
\text { and perceptions } \\
\text { about child } \\
\text { weight. }\end{array}$ & $\begin{array}{l}\text { Mothers } \\
\text { (child } \\
\text { aged 2-5 } \\
\text { years) }= \\
101\end{array}$ & $\begin{array}{l}\text { Country, US } \\
\text { Age, years range 20-35 } \\
\text { Race/ethnicity/culture/language, White: } 50 \% \text {, } \\
\text { African American: 24\%, Hispanic American: } \\
27 \%\end{array}$ & $\begin{array}{l}\text { Focus groups } \\
\text { held in } \\
\text { conference } \\
\text { rooms of } \\
\text { health } \\
\text { department } \\
\text { clinics and in } \\
\text { classrooms of } \\
\text { Pennsylvania } \\
\text { State } \\
\text { University } \\
\text { campus. }\end{array}$ & $\begin{array}{l}\text { Participants recruited from three Atlanta } \\
\text { WIC SNAP clinics. Eligible mothers } \\
\text { had family income } \leq 185 \% \text { poverty } \\
\text { level, were not employed in the health } \\
\text { field, were aged } 20-35 \text { years, could } \\
\text { communicate in English or Spanish, } \\
\text { lived in an urban or suburban area, self- } \\
\text { identified as white, African } \\
\text { American, or Hispanic American and } \\
\text { had at least one child (whom they were } \\
\text { primarily responsible for feeding) aged } \\
2 \text { to }<5 \text { years old living with them free } \\
\text { of diet-related health conditions. } \\
\text { Additional middle-income white parents } \\
\text { from the state College, Pennsylvania } \\
\text { area were recruited from prior studies on } \\
\text { child feeding and weight (same } \\
\text { eligibility criteria although }>185 \% \\
\text { poverty level). }\end{array}$ & $\begin{array}{l}\text { Observational, } \\
\text { cross-sectional } \\
\text { using } \\
\text { qualitative } \\
\text { methods: } \\
\text { qualitative } \\
\text { focus groups }\end{array}$ & $\begin{array}{l}\text { Focus group } \\
\text { discussions were } \\
\text { led by an } \\
\text { anthropologist } \\
\text { fluent in English } \\
\text { and Spanish, and } \\
\text { experienced in } \\
\text { focus-group work } \\
\text { among whites, } \\
\text { African } \\
\text { Americans, and } \\
\text { Hispanics. }\end{array}$ & $\begin{array}{l}\text { Transcripts were coded by two } \\
\text { authors and typed themes into a } \\
\text { master table for comparisons } \\
\text { within racial/ ethnic and income } \\
\text { categories. Key findings were } \\
\text { defined as themes that arose in all } \\
\text { three groups within a racial/ethnic } \\
\text { or income category or across the } \\
\text { majority of all groups. All co- } \\
\text { authors met several times to review } \\
\text { findings and reach consensus on } \\
\text { the major group themes. }\end{array}$ \\
\hline $\begin{array}{l}\text { Younginer } \\
\text { et al. } \\
\text { (2016) (47) }\end{array}$ & $\begin{array}{l}\text { To examine } \\
\text { definitions } \\
\text { of snacks among a } \\
\text { diverse sample of } \\
\text { low-income urban } \\
\text { caregivers of } \\
\text { preschool-aged } \\
\text { children. }\end{array}$ & $\begin{array}{l}\text { Parents } \\
\text { (child } \\
\text { aged 3-5 } \\
\text { years) }= \\
59\end{array}$ & $\begin{array}{l}\text { Country, US } \\
\text { Gender, Female: } 93 \% \\
\text { Age, mean (SD) years: } 31.2 \text { (8.4) } \\
\text { Race/ethnicity/culture/language, White: } 28 \% \text {, } \\
\text { African American: } 38 \% \text {, Hispanic or Latino: } \\
33 \% \text {, speaks only or mostly Spanish: } 20 \% \\
\text { Socioeconomic status, high school/GED or less } \\
47 \% \text {, employed: } 41 \% \text {, WIC participant: } 70 \% \text {, } \\
\text { recipient of Food Stamps: } 80 \% \text {, free/reduced } \\
\text { school meals: } 47 \% \text {, Head Start program: } 35 \% \text {, } \\
\text { food insecurity in last } 12 \text { months: } 43 \% \\
\text { Marital status, married or living with partner } \\
38 \% \\
\text { Weight status, overweight or obese: } 68 \%\end{array}$ & $\begin{array}{l}\text { Interviews } \\
\text { conducted in } \\
\text { a research } \\
\text { setting. }\end{array}$ & $\begin{array}{l}\text { Participants were low-income caregivers } \\
\text { aged } \geq 18 \text { years primarily mostly } \\
\text { responsible for feeding their } 3-5 \text {-year- } \\
\text { old child (free of severe food allergy or } \\
\text { condition that influenced feeding), } \\
\text { recruited from urban Philadelphia and } \\
\text { the Greater Boston Area using flyers } \\
\text { posted in WIC SNAP offices and online } \\
\text { community lists. }\end{array}$ & $\begin{array}{l}\text { Observational, } \\
\text { cross-sectional } \\
\text { using } \\
\text { qualitative } \\
\text { methods: } \\
\text { qualitative } \\
\text { semi-structured } \\
\text { interviews }\end{array}$ & $\begin{array}{l}\text { Details of their } \\
\text { characteristics not } \\
\text { provided. A } \\
\text { bilingual research } \\
\text { assistant } \\
\text { conducted } \\
\text { interviews in } \\
\text { Spanish. }\end{array}$ & $\begin{array}{l}\text { Transcripts were coded by two } \\
\text { trained researchers. Transcript } \\
\text { passages were organized by } \\
\text { interview question, } 50 \% \text { of } \\
\text { transcripts were then open-coded } \\
\text { by one coder to identify themes, } \\
\text { open-coding was checked by the } \\
\text { second coder for agreement, the } \\
\text { primary coder then open-coded the } \\
\text { remaining } 50 \% \text { of transcripts. } \\
\text { Axial coding was conducted to } \\
\text { identify relationships between open } \\
\text { codes and selective coding was } \\
\text { used to identify themes related to } \\
\text { the research question. Coders } \\
\text { verified coding at monthly } \\
\text { meetings until all transcripts had } \\
\text { been coded and organized into } \\
\text { dimensions. }\end{array}$ \\
\hline
\end{tabular}

Abbreviations: BMI, Body Mass Index; EBT, Electronic Benefits Transfer program; GCSE, General Certificate of Secondary Education; GED, General Equivalency Diploma (high-school level); SD, Standard Deviation; SNAP, Supplemental Nutrition Assistance Program; UK, United Kingdom; US, United States; USD, United States Dollar.

Plating up appropriate portion sizes for children 